TOMASZ JE $\dot{Z}$

UNIWERSYTET WARSZAWSKI

\title{
JEZUICKI REPERTUAR MUZYCZNY W KLASZTORZE KANONICZEK REGULARNYCH WE WROCEAWIU
}

$W$ rocławski konwent kanoniczek regularnych św. Augustyna na Piasku był na przełomie XVII i XVIII w. ważnym centrum kultury muzycznej dawnego Śląska. O randze tego ośrodka dobitnie zaświadcza sporządzony w nim zbiór około 450 rękopisów muzycznych, po kasacie zakonu przechowywany w Musikalisches Institut bei der Universität Breslau, a obecnie - w Gabinecie Zbiorów Muzycznych Biblioteki Uniwersyteckiej w Warszawie. Rękopisy te stanowią unikatową w skali całego kraju kolekcję muzykaliów swojej epoki: ujawniają przede wszystkim wysoki poziom kultury muzycznej wrocławskich kanoniczek; poświadczają również rozległe ich kontakty z wieloma ośrodkami europejskimi. Na szczególną uwagę zasługują związki konwentu z centrami muzycznymi, które miały decydującą rolę dla krzewienia nowych tendencji stylistycznych. Repertuar wrocławskich kanoniczek ujawnia nadto liczne filiacje $\mathrm{z}$ innymi śląskimi ośrodkami zakonnymi, kształtującymi w kontekście nieco bardziej regionalnym kultywowane na Piasku tradycje muzyczne ${ }^{I}$.

Jednym z tego typu środowisk był zakon jezuitów, który z bezprecedensowym powodzeniem potrafił łączyć strategie uniwersalizujące $\mathrm{z}$ aktywnością na rzecz środowisk lokalnych, co w przemożny sposób oddziałało na ówczesną kulturę, również muzyczną. W rękopisach wrocławskich kanoniczek regularnych znajdujemy liczne ślady zainteresowania ich kopistek najnowszą twórczością muzyczną jezuitów, czynnych nie tylko na terenie Śląska, ale też w innych ośrodkach prowincji czeskiej oraz w sąsiedniej Rzeczpospolitej Obojga Narodów. Trafiły tu m.in. kompozycje takich jezuitów, jak Georg Braun, Joannes Faber, Martin Kretzmer, Leopold Liebstein, Karl Pelikán, Karl Pfeiffer i Karl Rabovius. Są tu także unikatowe kopie utworów organisty jezuickiego kościoła Wniebowzięcia Najświętszej Marii Panny

I Zob. Adam Mrygoń, „Dolnośląskie rękopisy muzyczne w zbiorach Biblioteki Uniwersyteckiej w Warszawie", w: Beiträge zur Musikgeschichte Schlesiens. Musikkultur - Orgellandschaft, Tagungsbericht Liegnitz I99I, red. Jarosław Stępowski, Helmut Loos, Bonn I994, s. 285-29I. 
w Kłodzku, którym przez ponad czterdzieści lat był Nicolaus Franciscus Frölich. Wrocławskie kanoniczki interesował również repertuar przekazany anonimowo, wykazujący ewidentne cechy muzyki popularnej wówczas w kręgach jezuickich. Skąd jednak wynikało tak duże zainteresowanie wrocławskich kanoniczek jezuickim repertuarem muzycznym?

Pytanie to pojawiło się po raz pierwszy jakiś czas temu, gdy w ramach projektu badawczego pt. Repertuar muzyczny Towarzystwa Jezusowego w Rzeczpospolitej Obojga Narodów (I565-I773), realizowanego przez Uniwersytet Warszawski i finansowanego przez Ministra Nauki i Szkolnictwa Wyższego w ramach modułu „Tradycja Ia” programu pod nazwą Narodowy Program Rozwoju Humanistyki, międzynarodowy zespół badaczy z Polski, Niemiec, Włoch, Czech, Słowacji, Ukrainy, Białorusi, Rosji, Litwy, Łotwy i Szwecji rozpoczął - w nowej serii Fontes Musicae in Polonia - publikowanie tomów z muzykaliami kompozytorów jezuickich; okazało się wówczas, że większość zachowanego do dziś repertuaru jezuickiego proweniencji śląskiej zachowała się właśnie w zbiorze muzykaliów wrocławskich kanoniczek regularnych in Arena Wratislaviense. Aby odpowiedzieć na postawione wyżej pytanie, należałoby najpierw scharakteryzować profil uprawianej w tym ośrodku kultury muzycznej. Nie będzie to jednak zadanie łatwe, bowiem zagadnienie to nie było jak dotąd przedmiotem samodzielnych studiów muzykologicznych. Istnieje jednak parę przyczynków, wstępnie poruszających ten temat z perspektywy historycznej; sam repertuar wrocławskich kanoniczek został też wprowadzony do bazy RISM ${ }^{3}$ i potwierdzony jako oryginalny zasób proweniencyjny ${ }^{4}$.

Konwent kanoniczek regularnych działał na wrocławskim Piasku już pod koniec XIII w., kiedy to niejaki Giselher Colneri nadał im (w roku 1299) prawa do części dawnego dworu położonego naprzeciwko kościoła Najświętszej Maryi Panny,

2 Ludwig Burgemeister, „Das ehemalige Jakobkloster auf der Sandinsel zu Breslau”, Zeitschrift des Vereins für Geschichte Schlesiens 37 (1903), s. 249-259; Hermann Hoffmann, Sandstift und Pfarrkirche St. Maria in Breslau. Gestalt und Wandel im Laufe der Jahrhunderte, Stuttgart-Aalen 1971, s. 57-72; Anna Pobóg-Lenartowicz, „Kanoniczki na wrocławskim Piasku. Perspektywy badawcze”, w: Sanctimoniales. Zakony żeńskie w Polsce i Europie Środkowej (do przetomu XVIII i XIX wieku), red. Andrzej Radzimiński, Dariusz Karczewski, Zbigniew Zyglewski, Bydgoszcz-Toruń 20I0, s. I83-194; Joanna Heluszka, „Stan badań nad dziejami klasztoru kanoniczek regularnych pw. św. Jakuba we Wrocławiu", Studia Teologiczno-Historyczne Ślaska Opolskiego 34 (20I4), s. 23I-243; Anna Sutowicz, „Zapomniany klasztor Panien Kanoniczek na wrocławskim Piasku", http://www.nowezycie.archidiecezja.wroc.pl/stara_strona/numery/ı220II/o9. html, dostęp I2 VII 2017.

3 Ewa Hauptman-Fischer, Katarzyna Spurgjasz, „Sprawozdanie zinwentaryzacji muzykaliów poklasztornych w Gabinecie Zbiorów Muzycznych Biblioteki Uniwersyteckiej w Warszawie w dniach I V-30 X 2013 r.", Hereditas Monasteriorum 5 (2014), s. 470-483, 6 (2015), s. 499-5II, 7 (20I5), s. 542.

4 Remigiusz Pośpiech, Muzyka wielogtosowa w celebracji eucharystycznej na Ślasku w XVII i XVIII wieku, Opole 2004; Ewa Hauptman-Fischer, „Muzykalia poklasztorne w Gabinecie Zbiorów Muzycznych Biblioteki Uniwersyteckiej w Warszawie - identyfikacja i inwentaryzacja”, Hereditas Monasteriorum I (20I2), s. $438-44$ I. 
użytkowanego od połowy XII w. przez męski klasztor tego samego zgromadzenias. Konwent żeński przyjął stosowaną przezeń regułę św. Augustyna i podporządkował się jego administracji zakonnej. Pod koniec XIV w. Jan z Pragi, opat kanoników klasztoru na Piasku (1376-86), udostępnił mniszkom zbudowany przez siebie kościół św. Anny, początkowo pełniący funkcję kaplicy cmentarnej ${ }^{6}$. Gruntowną reformę obydwu konwentów przeprowadził Jodok z Głuchołaz (opat w l. 1429-47), który jeszcze silniej przyporządkował konwent żeński męskiemu i obydwie wspólnoty wyłączył z kongregacji arrowezyjskiej. Kanoniczki z wrocławskiego Piasku dążyły jednak do samodzielności, o czym świadczy zawarcie przez nie w roku I5I 5 konfraterni z rzymskim Ospedale di Santo Spirito in Sassia, a w I653 r. włączenie ich konwentu do kongregacji kanoniczek regularnych św. Jakuba w podwiedeńskim Heiligenstadt ${ }^{7}$. W tej ostatniej agregacji czynny udział mieli zresztą dwaj opaci konwentu NMP na Piasku: Johann Scherer (163I-55) i Georg Pohl (I657-77), gorliwie wprowadzający w obydwu konwentach potrydenckie reformy ${ }^{8}$.

Dotyczyły one przede wszystkim gruntownej odnowy życia duchowego i powrotu do charyzmatów wskazanych profeskom kanoniczek przez regułę św. Augustyna. Ta zaś zalecała m.in. praktykowanie uczynków miłosierdzia, które wrocławskie mniszki spełniały w pobliskim szpitalu przeznaczonym dla najuboższych mieszkańców miasta. Wymagała także powrotu do ideału zakonnej ascezy, symbolizowanej przez strój zakonny, który w trakcie reformy uległ znaczącym modyfikacjom. Wiązała się wreszcie z reformą śpiewu liturgicznego, który od początku istnienia wrocławskiego konwentu był fundamentem jego wspólnoty zakonnej’; po reformie miał być jednak śpiewany $\mathrm{w}$ wersji zalecanej przez rzymską, posoborową edycję brewiarza. Poza chorałem, kanoniczki z Piasku uprawiały również muzykę wokalno-instrumentalną: kapelę złożoną $\mathrm{z}$ utalentowanych muzycznie zakonnic zorganizowała Ursula Birkholtz, przeorysza tego konwentu w 1. 1659-9 $6^{10}$. Z czasów jej kadencji do dziś zachowało się około I80 rękopisów muzycznych, które do roku I687 opatrywano notą proweniencyjną „Chori S. Annae”, a później „Chori S. Jacobi”, bo właśnie temu apostołowi dedykowano nowy ich kościół, wznoszony w l. 1687-9I ${ }^{\mathrm{II}}$.

W kolejnych latach kanoniczki budowały nowy gmach klasztoru, do którego przeniosły się w roku 1715. Parę lat później przeprowadzona tam została wizytacja kanoniczna, z której zachował się protokół, informujący m.in. o paru szczegółach

\footnotetext{
5 A. Pobóg-Lenartowicz, op. cit., s. I87.

6 H. Hoffmann, op. cit., s. 74.

7 A. Pobóg-Lenartowicz, op. cit., s. I9I, 193.

8 H. Hoffmann, op. cit., s. 59.

9 Anna Sutowicz, Kultura religijna mniszek ślaskich w okresie średniowiecza, Legnica 2016, s. 228.

Io Ewa Hauptman-Fischer, „Musical gifts. Dedications in Silesian music manuscripts of monastic provenance”, Polski Rocznik Muzykologiczny I5 (2016), s. 57-82, zob. s. 60.

II L. Burgemeister, op. cit., s. 249-259, zob. s. 252-254.
} 
z życia muzycznego klasztoru ${ }^{\mathrm{I2}}$. Podano tam na przykład, że mszy świętej otwierającej tę wizytację towarzyszyła wykonywana przez mniszki muzyka wokalno-instrumentalna ${ }^{13}$. Omawiany dokument poświadcza również czynny udział zakonnic w oficjach liturgii godzin i mszy świętej, odprawianych niekiedy z udziałem muzyki; jej przygotowaniu służyły popołudniowe ćwiczenia muzyczne odbywane codziennie między obiadem a nieszporami ${ }^{\mathrm{I}}$. Za wykonania muzyczne odpowiedzialna była kantorka, wymieniona w aktach wizytacji zaraz po przeoryszy i mistrzyni nowicjatu (ten ostatni urząd piastowała wtedy Maria Teresa Bannerin, być może tożsama ze skrzypaczką wzmiankowaną w paru wcześniejszych rękopisach badanej proweniencji ${ }^{15}$ ). W roku I7I9 urząd kantorki pełniły dwie, zmieniające się co tydzień, zakonnice: Anna Catharina Andresin oraz Victoria Helwegin. Druga z nich była jednocześnie zakrystianką, co zwykle wiązało się z odpowiedzialnością za dystrybucję nut dla kapeli; również i ta funkcja była wtedy dzielona przez dwie osoby ${ }^{16}$. Ogółem, cały konwent w czasie wizytacji liczył osiemnaście mniszek, pochodzących przede wszystkim ze Śląska; w tym aż siedem z katolickiej Nysy, co być może ma jakieś znaczenie dla podejmowanego tu zagadnienia. Istotne w tej perspektywie jest także zawarte w protokole wizytacyjnym zalecenie biskupa, który nakładał na zakonnice konwentu obowiązek regularnego odbywania ćwiczeń rekolekcyjnych ${ }^{17}$.

Jak wiadomo, specjalistami w zakresie prowadzenia rekolekcji byli w tym czasie jezuici, którzy opracowane przez Ignacego Loyolę Ćwiczenia duchowne stosowali nie tylko we własnej formacji zakonnej; doświadczeniami w tej dziedzinie dzielili się również chętnie z klerem diecezjalnym i członkami innych zakonów, także

Archiwum Archidiecezji Wrocławskiej (dalej jako AAW), II b 156: Visitatio Ecclesiae et Monasterii Monialium in Arena ad S. Annam Ordinis Canonicorum Regularium S. Augustini (1719), por.: Wincenty Urban, „Katalog Archiwum Archidiecezjalnego we Wrocławiu. Rękopisy”, Archiwa, Biblioteki i Muzea Kościelne Io (1965), s. 5-32, II (1965), s. 5-108, I2 (1966), s. 5-74, I3 (1966), s. 5-89, I4 (1967), s. 5-131, I5 (I967), s. 9I-248, I6 (I968), s. I9-242, zob.: II (I965), s. 39; A. Pobóg-Lenartowicz, op. cit., s. 193.

I3 AAW II b 156, k. [I]: „....ad altare majus, ubi prævia præparatione ad Mifsam, Sacrum perfolvi, sub quo Moniales Cantus aliquos figuraliter produxerunt, eo absoluto in præfentia Confefsarii Vifitationem Ecclesiæ profecutus fui, ut sequitur".

I4 AAW II b 156, k. [7]: „Mane hora $5^{\text {ta }}$ media ad surgendum pulfatur, et media $6^{\text {ta }}$ Moniales surgunt, accedentes hora $6^{\text {ta }}$ chorum, ubi primam abfolvunt, eaq(ue) finita usq(ue) ad septimam meditantur, peracta Meditatione abfolvunt tertiam, qua dicta singulæ Moniales legunt librum spiritualem hyemali tempore in Cellis, in æftate autem in choro. Hora $8^{\text {va }}$ habentur Mifsa, quæ vel legit(ur) vel cantatur pro diverfitate temporum [...]. Sub menfa legitur in quadragefima toto tempore, extra quadragefimam autem media hora, prandio finito quævis pro libitu accedit chorum, salutando SS ${ }^{\text {mum }}$ deinde habent exercitium Muficæ, vel laborant ufq(ue) ad Vefperas quæ habentur hora secunda...”.

I5 Inskrypcje o treści „Verte Cito | Soror Maria | Teresia” oraz „Verte | Virgo Maria Teresia” pojawiają się w głosach Vl I kopii dwóch anonimowo przekazanych utworów: Te Deum Laudamus (PL-Wu RM 5482) i Dulcis Jesu amor mundi (PL-Wu RM 6392).

i6 AAW II b 156, k. [8]: „Primum Officium poft Priorifsam tenet Magiftra Novitiarum, et vocantur Maria Therefia Bannerin. Secundum officium eft Cantorifsa, quarum duæ sunt alternantes hebdomadatijn et vocantur Anna Catharina Andrefin, et Victoria Helwegin. Tertium Officium eft Sacriftiæ, quarum itrum duæ sunt, Anna Johanna Mentzelin, et Maria Victoria Helwegin".

I7 AAW II b i56, k. [I8]. 
żeńskich. Ich aktywność w tego typu duszpasterstwie na obszarze Śląska potwierdzają kroniki zakonne, wzmiankujące o rekolekcjach głoszonych przez jezuitów (często zresztą pochodzących właśnie z Nysy) dla augustianów z Żagania, urszulanek ze Świdnicy, bądź klarysek z Głogowa ${ }^{\text {I8 }}$. Praktyki tego typu dokumentują także analogiczne źródła z klasztorów żeńskich Rzeczypospolitej, np. klarysek w Starym Sączu, benedyktynek w Sierpcu czy brygidek w Grodnie ${ }^{19}$. Jezuici coraz częściej bywali zatrudniani w ich konwentach jako spowiednicy, kaznodzieje i specjaliści w zakresie prawa kanonicznego; drukowane przez nich medytacje stały się ulubioną lekturą zakonnic ${ }^{20}$, zaś na podstawie tworzonych przez nich pism mistycznych wiele klasztorów przeprowadziło gruntowne reformy życia duchownego własnych konwentów; niektóre z nich przystąpiły nawet do sodalicji mariańskich ${ }^{21}$. Wpływ jezuitów na życie religijne mniszek przejawiał się także w praktyce teatru zakonnego, który u benedyktynek w Sandomierzu, Jarosławiu i Przemyślu inspirowany był jezuickim dramatem szkolnym ${ }^{22}$.

Jak zauważyła Małgorzata Borkowska, zjawiska tego typu widoczne są szczególnie w tych klasztorach, które usiłowały się usamodzielniać od administrujących nimi dotąd męskich gałęzi tej samej denominacji zakonnej ${ }^{23}$. Przechodząc pod obediencję biskupa, mniszki oczywiście w dalszym ciągu potrzebowały księży (do sprawowania mszy świętej i odbywania spowiedzi); nie były już jednak „skazane” na tych wyznaczonych przez opata sąsiadującego z ich klasztorem konwentu męskiego, lecz mogły sobie wybrać zakonników bardziej doświadczonych w tych dziedzinach. Tendencja ta w jakimśstopniu mogła również dojść do głosu w konwencie kanoniczek wrocławskich, który wprawdzie nie zdecydował się na emancypację aż tak radykalną, jak wiele polskich zgromadzeń. Zachowując administracyjną podległość sąsiedniemu klasztorowi kanoników, Panny z Piasku poszukiwały jednak nowych źródeł inspiracji religijnej i odmiennych środków wyrazu, artykułowanych m.in. za pośrednictwem pielęgnowanej w ich środowisku kultury muzycznej. Zobaczmy więc, jak wyglądała ta ostatnia; uprzedzając interpretację tego zjawiska wynikającą z koniecznych jeszcze do przeprowadzenia studiów historycznych.

W zgromadzonym przez wrocławskie kanoniczki repertuarze muzycznym uwagę zwraca spora liczba kompozycji autorów niemieckich i włoskich. W tej pierwszej

I8 Tomasz Jeż, Kultura muzyczna jezuitów na Ślasku i ziemi ktodzkiej (I58I-I776), Warszawa 20I3, s. 239.

I9 Małgorzata Borkowska, Życie codzienne polskich klasztorów żeńskich w XVII-XVIII wieku, Warszawa 1996, s. $74-76$.

20 Np. Maciej Bogumił Grymosz, Święta przez pustynią zakonną droga do konsekracyi panieństwa wiekuistego oblubieńcowi niebieskiemu zaszlubionego, albo rozmyślania na dziesięć dni przed konsekracya panien zakonnych z samego prawie Pontifikatu..., Oliwa I69o Jan Jakub Textor.

2I Małgorzata Borkowska, „Jezuici i ich duchowość w oczach polskich mniszek XVI-XVIII w.", Życie Duchowe 2 (I995) nr 4, s. 99-II2.

22 M. Borkowska, Życie codzienne polskich klasztorów, op. cit., s. 32I.

23 M. Borkowska, „Jezuici i ich duchowość”, op. cit., s. IoI. 
grupie wspomnijmy dwie sonaty instrumentalne Johanna Heinricha Schmelzera $(\mathrm{I} 623-80)^{24}$ i wielkoobsadowy koncert Philippa Jacoba Baudrexela (I627-9I) ${ }^{25}$. Wśród autorów włoskich znana była na Piasku twórczość takich autorów, jak Antonio Bertali (I605-69) ${ }^{26}$, Natale Monferrato (I6I5-85) ${ }^{27}$, Antonio Cesti (I623-69) ${ }^{28}$ i Vincenzo Albrici $(\mathrm{I} 63 \mathrm{I}-87)^{29}$. Powyższa lista nazwisk dobitnie zdaje sprawę z dobrej orientacji wrocławskich kanoniczek w najciekawszych nurtach współczesnej twórczości muzycznej powstającej w katolickich ośrodkach Niemiec i muzycznych centrach północnej Italii. Nieco bliższą perspektywę stylistyczną wyznaczają nazwiska kompozytorów czeskich, takich jak Adam Václav Michna z Otradovic (I6oo-76) ${ }^{30}$, Jan Jiř́ Abersbach (ok. I663-73) ${ }^{31}$ i Samuel Zindel (zm. I703) ${ }^{32}$; co ciekawe, wszyscy trzej byli wykształceni w konwiktach jezuickich, a swoją twórczością poświadczają oni lokalną recepcję stylistyki włoskiej. Bezpośredni kontekst dla interesującego tu nas zagadnienia stanowi jednak twórczość kompozytorów reprezentujących śląskie (w tym także wrocławskie) środowiska zakonne. Są wśród nich oczywiście kanonicy

24 PL-Wu RM 4925 (olim: Mf 974; RISM: 3005I0705): Sonata de Nativitate. | a. 8. | 2. Violin: | 2. Clarin: | 3. Viole. | et | Organo. | Di S:re. Gio. Hen: |Schmelzer. | Chori S: Anne| I682.; PL-Wu RM 4926 (olim: Mf 975; RISM: 3005I0706): Sonata ã 6. |Violino-2 |Viol. -3 | et $\mid$ Violone $\mid$ Con Organo. $\mid$ Authore D(omi)no | Joanne Henrico | Schmelzer. | Chori S: Anne | I682.

25 PL-Wu RM 608I (olim: Mq 2I; RISM: 300511883): De Virginibus. | Regnum mundi \& omnem ornatum. |ä I3. $\mid 2$ - Cant. |2-Alt. |2-Tenor. |2-Bafs. |2-Violin. |3-Trombon. |\& Organo. | Authore R: D: Philippio |Jacobo Baudrexel. | Chori S: Jacobi | 1689.

26 PL-Wu RM 6076 (olim: Mq I7; RISM: 300510719): Egredimini Filice Sion |ã I4. | 2 CC: IA: 2 T: T: I Bafs: | 2 VV: 2 Viole 2 Trombon | 2 Clarin Violon et ORgano |Authore Sig: Antonio Barthali [!] | Chori S: Anne | I682; PL-Wu RM 6075 (olim: Mq I6; RISM: 300511890): Salve Regina. |ã I3. | 2 - Cant. |I-Alt. |ITenor. |I-Bass. | 2 Violin. | 3 Viola. |3 Capella. |\& organo. |Authore Barthali. [!] | Chori. S: Jacobi. | I688.

27 PL-Wu RM 6245 (olim: Mq I7I; RISM: 3005II840): Aue Regina Calorum. | a 2. | Canto et Alto. | Con Organo. | Chori S: Jacobi. | I698. | Authore D: Natal| Monferrato.

28 PL-Wu RM 6366 (olim: Mq 272; RISM: 300511784): Chare Jesu. |ã 8. | Canto Solo. 2. Violin. |2. Cornett. 3. Viole. | \& Organo. | Chori S: Jacobi. | 1697.

29 PL-Wu RM 6062 (olim: Mq 5; RISM: 300511893): Hymnus de Confessoribus. |ã 9. | Cant. Alt. Tenor. Bafs. | 2. Violin. 2. Viola. | \& Fagotto. seu. 3. Trombon. | Con Organo. |Authore S(i)g(no)re: Vincentio |Alberici | Chori S: Jacobi. | 1695 .

30 PL-Wu RM 4684 (olim: Mf 773; RISM: 3005I4472): Te Deum Laudamus | a I3. | 2 - Cantus. | 2 - Alt. | 2-Tenor $\left|2-B a \int_{s}\right| 2$-Violin $\mid 2$-Viole $\mid$ et Violon Bafso Continuo $\mid$ Authore Adamus $\mid$ Michna $\mid$ Chori S: Anne | I68I.

3I PL-Wu RM 6058 (olim: Mq I; RISM: 3005I07I8): Litanie B. M. V: |ä 9 | C. A. T. B. 2 Violin. | 3 Trombon. | Authore Joanne | Aberspach. | Chori S: Anne. | I68I.

32 PL-Wu RM 6317 (olim: Mq 227; RISM: 300510756): Lÿtania de B: Virgine|Maria ã 1o. | 2 CC: Alt. Tenor Bafso, | 2. Violin 3 Trombon, | et organo. | Authore D: Samuele. | Zindelio. | Chori S: Anne | I68I; PL-Wu RM 509I (olim: Mf I098; RISM: 3005I4477): Offertorium De Nativitate $\mid$ Christi $\mid a ̃$ I4 $|C .-I|$ Alt $-I \mid$ Tenor $-I \mid$ Bass $-I \mid$ Violin - 2 $\mid$ Clarin - 2 $\mid$ Mars Principal Tympano $\mid$ Trombon - 3|Et ORgano $\mid$ Quem Vidistis Pastores | Chori S. Anne | I680|Authore. D(omi)no. |Samuele Zindel. 
regularni (Johann Georg Brotz) ${ }^{33}$, ale także norbertanie (Jiří Melzel) ${ }^{34}$, dominikanie (Alanus Leonardus de Rupe) ${ }^{35}$ i franciszkanie (Bernardus Artophaeus) ${ }^{36}$. Duchowość tego ostatniego zgromadzenia niewątpliwie musiała być bliska obydwu konwentom wrocławskiego Piasku, od dawna pielęgnującym ożywione kontakty z europejskimi ośrodkami nurtu devotio moderna ${ }^{37}$.

W połowie XVII w. franciszkanie podlegali już jednak nowemu nurtowi mistycyzmu, którego najwybitniejszym na Śląsku reprezentantem był Johannes Scheffler. Po swojej konwersji na katolicyzm Angelus Silesius wstąpił do Trzeciego Zakonu św. Franciszka ${ }^{38}$ i był autorem kilku zbiorów poezji mistycznej, inspirowanych seraficką koncepcją drogi samodoskonalenia duchowego ${ }^{39}$. Współpracował jednak także z innymi środowiskami zakonnymi regionu, m.in. krzeszowskimi cystersami, z którymi, opierając się na pismach mistycznych św. Piotra z Alkantary ${ }^{40}$, opracował oryginalny program duszpasterstwa ludowego. Realizowany on był w zakładanych

33 PL-Wu RM 6092 (olim: Mq 32; RISM: 300511895): Confitebor. |ã I2. | Cant-2. | Alt - I. | Tenor - I. | Bafs-I. |Violin - 2. | Clarin-2. | Trombon-3. | \& Organo. | Authore Domino Joanne. | Georgio Brotz. Chori S: Jacobi. | I697; PL-Wu RM 6093 (olim: Mq 33; RISM: 300512017): Hymnus. | De SS: Trinitate. ã s. | Alto Solo. 2. Violin. |2. Viole. \& Organo. |Chori S: Jacobi. | I70o. Authore R: D(omi)no: | P: Joanne Georgio | Brotz. Ord: S: Aug: | Can: Reg: Lat:; PL-Wu RM 6097 (olim: Mq 37; RISM: 300512020): Cantus. de S: Josepho. |â 9. | Alto Solo. 2. Violin. |Alt Viola. 2. Clarin. | Principal. Mars. Tympano. | Cum Organo. | Chori S: Jacobi. | I70o. | Authore R: P: |Joanne Georgio. | Brotz. Ord: S: Aug. | Can: Reg: Lat.

34 PL-Wu RM 4680 (olim: Mf 769; RISM: 3005I4473): VESPERA Mariane.|ã Io. Vocibus ó 6.|2. CC I. A. I. T. I. B. 2. VV: 3. Viole. |3. Trombon et 3. Ripienni. [!] | Cum Bafso Generali. |Authore R(everen)do P(at)re Joanne Melzelio Ord: | Premonst: | Chori S: Anne | 1683.

35 PL-Wu RM 629I (olim: Mq 207; RISM: 3005I0753): Offertoria De Sanctis | Apoftolis uel Martyribus | Sancti tui Domine florebunt. |ã Io Vocibus. | CC. A. T. B. VV. A. T. B. Viole |ô Tromb. et Organo. |Authore R. P. Alano |Leonardo De rupe Ord: | Predic: | Chori S: Anne | I683; PL-Wu RM 6292 (olim: Mq 208; RISM: 300510754): Offertorium De Sanctis Apostolis | uel Martyribus Tempore Pafchali. | Sancti et Jufti in D(omi)no gaudete. |ã ro. Vocibus. | CC. A. T. B. VV. A. T. B. Viole | o Tromb. et Organo. |Authore R. P. Alano | Leonardo De Rupe Ord: | Predic. | Chori S: Anne | I683.

36 PL-Wu RM 6064 (olim: Mq 7; RISM: 300511885): Litanie Lauretane | B: V: M. | Canto Precinente. Canto. Alto. Tenore. Bafso. |2. Violin. 3. Trombon.|\& Organo. |Authore P: Bernardo |Artophao. ord: Min: | Con: S: Francisci. Chori S: Jacobi. | I723; PL-Wu RM 6065 (olim: Mq 8; RISM: 3005II886): Litania Lauretane | B: V: Marie |a 9. | Cant. Alt. Tenor. Bafs. |2. Violini. 2. Viole. Violon. \& organo. | Authore Artophao. | Chori S: Jacobi | I690; PL-Wu RM 6066 (olim: Mq 9; RISM: 3005II888): Litanie Lauretane. | de B: M: Virginis. |ã 9. | Cant. Alt. Tenor. Bafs. |2. Violin. 3 Viole o Tromb: | \& organo. | Authore P: Bernardo Artopheo. |ord: Min: Con: S: Fran: | Chori S: Jacobi.| I69I; PL-Wu RM 607I (olim: Mq I3; RISM: 3005II880): Mottetum de S: Sebastiano. | siue. | De Quocumq(ue) alio Sancto. |ã Is w. | I-Cant. $\mid$ I-Alt. | I-Tenor. |I-Bafs. | 2 - Viololin [!]. | 2-Clarin. |3-Trombon. I \& organo. |Authore Fr(atr)e Bernardo | Artopheo. ord: min: con: | S: Francisci. | Chori S: |Jacobi. | I69I; PL-Wu RM 6072 (olim: Mq I4; RISM: 3005II879): Concertus de Resurrectione. | Surrexit Pastor bonus. | ä 6: | Canto Solo. 2. Violin. | 3. Viole \& organo. |Authore fr(atr)e. Bernardo |Artopheo. ord: Min: Con: | S: Francisci. | Chori S: Jacobi. | I69I.

37 Anna Pobóg-Lenartowicz, Kanonicy regularni na Śląku. Żcie konwentów w ślaskich klasztorach kanoników regularnych w średniowieczu, Opole I999, s. I79, I94.

38 Georg Ellinger, Angelus Silesius. Ein Lebensbild, Breslau I927, s. I65.

39 Kamila Janina Wiśniewska, Teologia Angelusa Silesiusa (Johannesa Schefflera), Warszawa 1984, s. 43.

40 Meditationes sancti Petri de Alcantara Hispani ordinis S. Patris Francisci, Reform: a Clemente papa IX canonizati anno I669, Aprilis 28, ex Hispanico translatae in latinum \& demum reimpresse, Kłodzko I686 Andreas Pega. 
przez cystersów konfraterniach św. Józefa, których członkowie celebrowali mistyczne zaślubiny duszy z Trinitas terrestris (Jezusem, Marią i Józefem) ${ }^{41}$. Silesius współpracował także ze śląskimi jezuitami, udzielając się w założonej przez nich sodalicji Oczyszczenia Najświętszej Maryi Panny we Wrocławiu. Wśród członków tego bractwa rozprowadzał różnego rodzaju literaturę dewocyjną, a także własnego autorstwa pieśni, m.in. popularną do dziś Ich will dich lieben meine Stärcke ${ }^{42}$. Można domniemywać, że w środowisku tym znane były opracowania jego tekstów umuzycznione przez Georga Josepha, kapelmistrza biskupa wrocławskiego Leopolda Wilhelma Habsburga ${ }^{43}$.

Pieśni ze zbioru Heilige Seelen-Lust Schefflera znajdujemy również w kilku rękopisach kanoniczek wrocławskich; opracowane w każdym z nich w nieco inny jednak sposób. Pieśń O Jesu, du verliebter Gott ( $V$. Sie beklagt sich gegen ihren Geliebten wegen seines langen Außenbleibens) pojawia się tam w trzech różnych wersjach melodycznych i fakturalnych: w opracowaniu na dwa alty i basso continuo ${ }^{44}$, na sopran, skrzypce, trzy wiole i basso continuo ${ }^{45}$ oraz $\mathrm{w}$ wersji na sopran, skrzypce, wiolę, wiolettę i organy ${ }^{46}$. Jako autor tego ostatniego opracowania na karcie tytułowej rękopisu podany jest niejaki „J. Gardawski” (il. I), którego z pełnym imieniem znajdujemy w kolejnym rękopisie tej samej proweniencji, zawierającym tak samo obsadzoną pieśń innego jezuickiego mistyka, Friedricha von Spee, Halt mein Herz nit eilen $d u^{47}$ (il. 2). Rękopis ten spisany jest inną ręką, należy więc przyjąć, że Jakub Gardawski był nie kopistą, ale autorem obydwu opracowań pieśni, nie wiadomo jednak, w jaki sposób związanym z klasztorem wrocławskich kanoniczek.

4I Andrzej Kozieł, Angelus Silesius, Bernhard Rosa i Michael Willmann, czyli sztuka i mistyka na Ślasku w czasach baroku, Wrocław 2006, s. 83-86.

42 Np. I20 egzemplarzy druku Compacta Philothei Anonymi Societatis amoris seu Spiritualis animae amantis cum Deo associatio, per pios affectus et praxes Divi Amoris explicata et a I. A. S. Sodalibus Theophilis in lucem edita, Wrocław I66I Baumann, por.: AAW, II b I29. Acta maioris Sodalitatis BV Maria Annunciate in Collegio Caesareo Soc. Jesu Wratislavice erecte, fol. 74r, zob.: Hermann Hoffmann, Die Marianische Männer-Kongregation Mariä Reinigung in Breslau 1638-1938, Breslau 1938, s. 15, 57, 62.

43 Heilige Seelen-Lust Oder Geistliche Hirten-Lieder Der in ihren Jesum verliebten Psyche Gesungen Von Johann Angelo Silesio, und von Herren Georgio Josepho mit außbundig schönen Melodeyen geziert, Breslau [I657] Gottfried Gründer [1657], zob.: Karl Fischer, „Angelus Silesius: Heilige Seelen-Lust. Die Stellung der Gesangweisen im generalbassbegleiteten Kirchengesang des 17. Jahrhunderts”, Kirchenmusikalisches Jahrbuch 84 (2000), s. 69-I00.

44 PL-Wu RM 6540 (olim: Mq 467; RISM: IooI0356r9): [s. t.]

45 PL-Wu RM 6572 (olim: Mq 499; RISM: 300510847): Affectus De |Jesu | Canto. Solo | et 4. Instrum. | et Organo | Chori S: Anne | I68I.

46 PL-Wu RM 6I58 (olim: Mq 89; RISM: 300510729): Cantus de Adventu D(omi)ni. | à 4. | Canto Solo | Violin Solo |2-Brazzio | et Bafso Continuo. |Authore J. Gardawsk̈| Chori S: Anna. | I679| 24 Novem:

47 PL-Wu RM 6I57 (olim: Mq 88; RISM: 3005I0728): Cantus de Vanitate | mundi |à 4. | Canto solo|Violino | 2 Violis. | Authore Jacobo | Gardawski. | Chori S: Anna. 


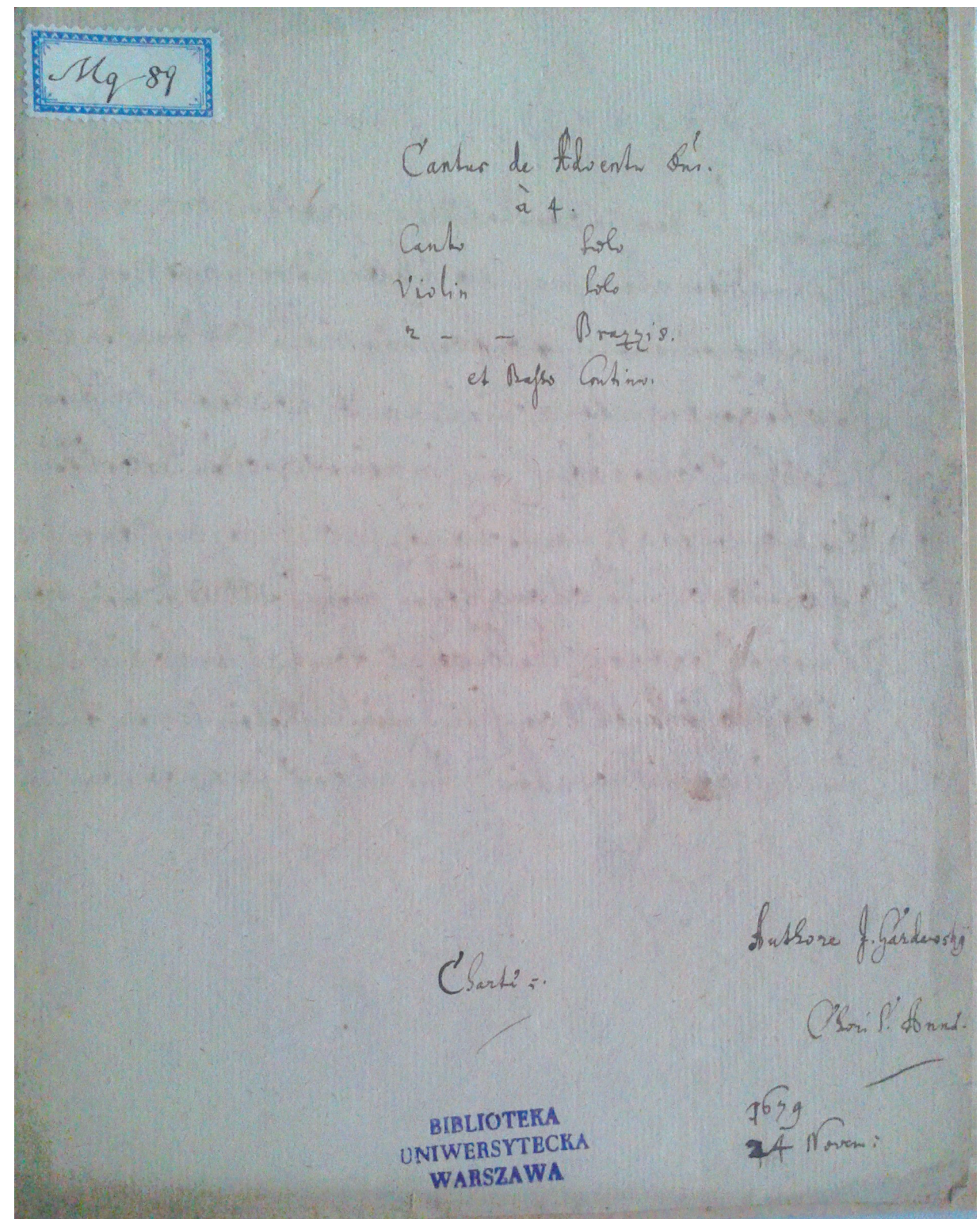

Il. I. PL-Wu RM 6158, Cantus de Adventu D(omi)ni à 4 [...] Authore J. Gardawsky [...], strona tytułowa. 


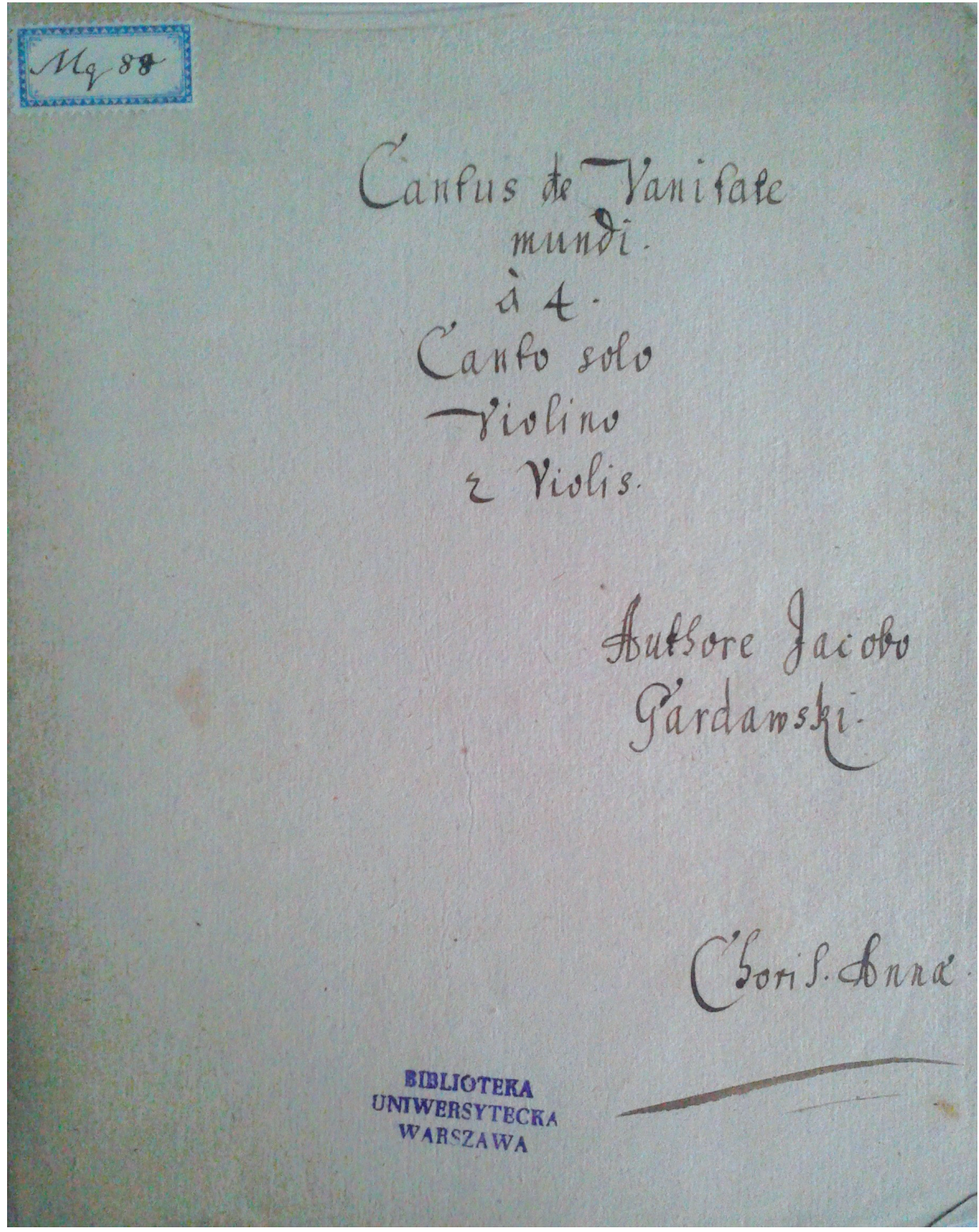

Il. 2. PL-Wu RM 6I57, Cantus de Vanitate mundi à 4. [...] Authore Jacobo Gardawski, strona tytułowa. 
Le fus<smiles>C#CC(C)(C)C#C</smiles>

Oulcis fesiu anto folo.

é 2 Yiolino

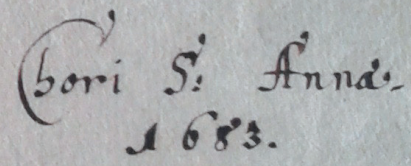

BIBLIOTERA

UNIWERSYTBCKA

WARSZAWA

Il. 3. PL-Wu RM 6392, Jesus. Maria. Joseph. Dulcis Jesu Canto Solo et 2 Violino [...], strona tytułowa. 


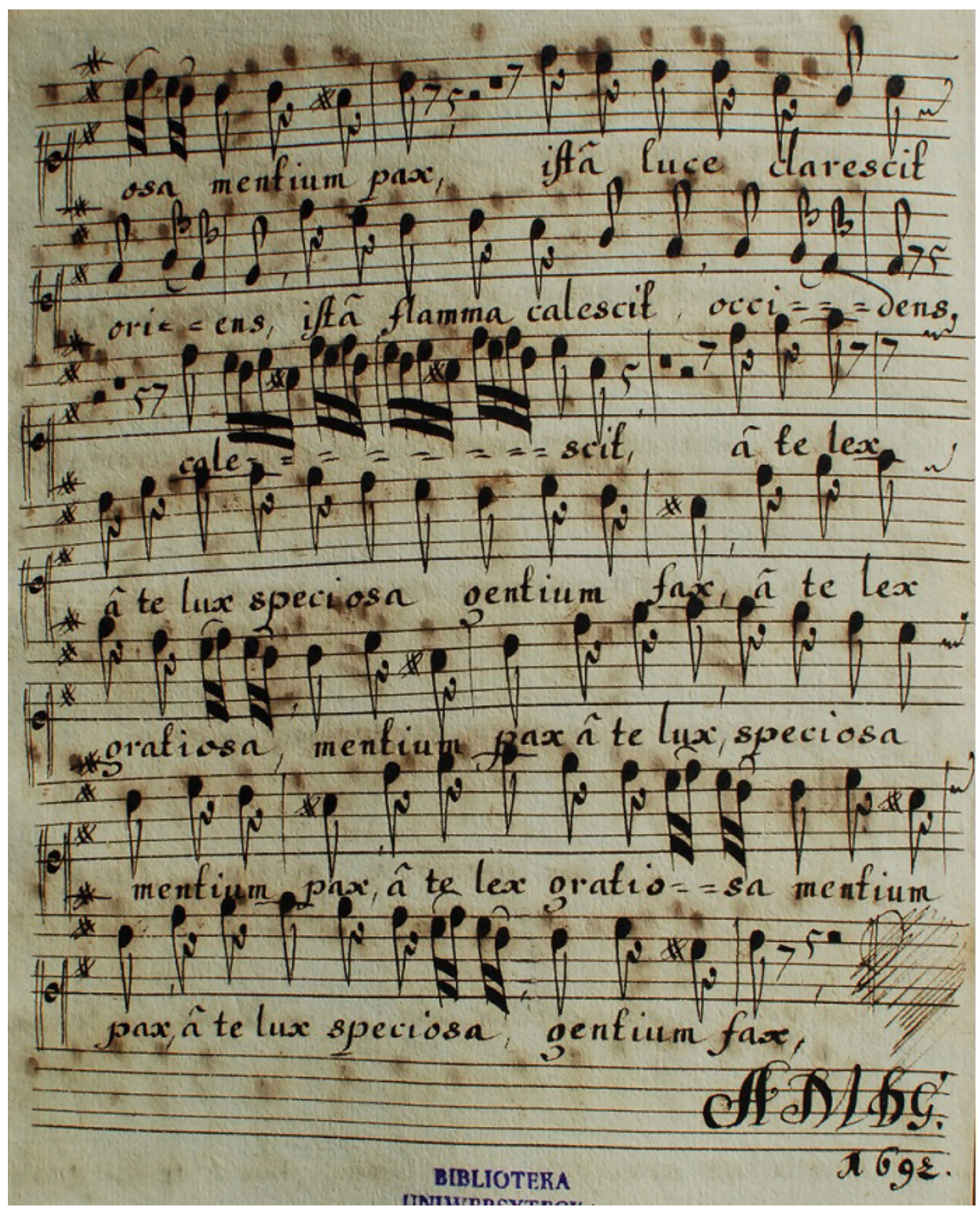

Il. 4. PL-Wu RM 6084, Georgius Braun SJ, In nomine Iesu â I2. [...], głos Canto. 
W ich zbiorach muzycznych zachowało się zresztą więcej pieśni o tematyce oblubieńczej, co można uznać za rzecz dość oczywistą w żeńskim konwencie zakonnym ${ }^{48}$. Innym tego przykładem może być napisana przez autora reguły, św. Augustyna, łacińska pieśń Amo te Deus meus ${ }^{49}$, opracowana na sopran solo i wiolę da gamba ${ }^{50}$, czy oparta na pismach św. Anzelma ${ }^{\text {sI }}$ podobnie obsadzona kompozycja Dulcis Jesu amor mundi $i^{2}$. Na stronie tytułowej rękopisu z tym ostatnim utworem widnieje zresztą dewiza "Jesus Maria Joseph" (il. 3), wskazująca na wzmiankowany wyżej program duszpasterstwa zorientowanego wokół idei Trinitas terrestris; warto tu dodać, że pojawia się ona (zwykle w wersji abrewiowanej: „Jhs Mra Joph”) w wielu rękopisach muzycznych wrocławskich kanoniczek, co świadczy o silnych związkach ich konwentu z animowanym przez Johannesa Schefflera i krzeszowskich cystersów nurtem duchowości oblubieńczej.

W równie wielu rękopisach muzycznych interesującej nas proweniencji pojawia się jeszcze druga dewiza: „ad majorem Dei gloriam”, występująca na kartach nut kopiowanych przez kanoniczki najczęściej w wersji skróconej: „A.M.D.Gl.” (il. 4); czasami jeszcze rozwiniętej o wątek mariologiczny do postaci „A.M.D.Gl.B.V.M.”. Zawołanie to kojarzone jest zwykle ze środowiskiem jezuickim, którego bezpośrednie związki z konwentem wrocławskich kanoniczek wymagają jeszcze gruntownych studiów historycznych. Już dziś możemy jednak zaryzykować tezę o bliskiej współpracy obydwu zgromadzeń zakonnych, którą pozwolimy sobie tu postawić na przykładzie jezuickiego repertuaru muzycznego zachowanego u Panien na Piasku. O ile bowiem obecność tej czy innej dewizy dowodzi mniej lub bardziej bezpośrednich odniesień ich wspólnoty do popularnych wówczas nurtów duchowości, to skopiowany do ich biblioteki repertuar świadczy o żywych kontaktach obydwu zakonów w przestrzeni interesującej nas tu kultury muzycznej.

Chronologiczną listę tych kompozycji otwiera skopiowany w roku I680 koncert Memorare o piissima Virgo Martina Kretzmera, jezuity pochodzącego z prowincji litewskiej Towarzystwa Jezusowego, który na Śląsku działał w 1. 1656-5953. Utwór ten opiera się na popularnej wśród jezuitów modlitwie maryjnej św. Bernarda z Clairvaux,

48 Robert L. Kendrick, Celestial Sirens. Nuns and their music in early modern Milan, Oxford 1996, s. 155-I8I.

49 Sancti Aurelii Augustini, Hipponensis Episcopi, opera omnia... opera et studio monachorum Ordinis Sancti Benedicti e congregatione Mauri..., Paryż 1837 Gaume, t. 6, s. I39I.

50 PL-Wu RM 6338 (olim: Mq 244; RISM: 300510758): Amo te ã 3 Canto Solo | Violino et Gamba | Chori S. Anne 1680.

5 I Sancti Anselmi ex Beccensi Abbate Cantuariensis archiepiscopi opera..., Wenecja 1744 Giuseppe Corona, t. I, s. 362.

52 PL-Wu RM 6392 (olim: Mq 298; RISM: 300510786): Jefus. Maria. Jofeph. | Dulcis Jesu Canto Solo. | et 2 Violino | Chori S: Anna | 1683.

53 PL-Wu RM 6228 (olim: Mq I56; RISM: 300510734): Memorare de B. M. V. |à 4 Alto Solo et 3 instrumen. | Authore Kretzmer | Chori S: Anne. | I680, por.: Martinus Kretzmer (I63I-I696). Sacerdotes Dei benedicite Dominum, Memorare o piissima Virgo, Aeterne rerum omnium effector Deus, Laudem te Dominum, red. Tomasz Jeż, Maciej Jochymczyk, Warszawa 2017 (= Fontes Musicae in Polonia C/I), s. 6. 
chętnie używanej przez wiele śląskich środowisk zakonnych. W tym samym roku I680 wrocławskie kanoniczki odpisały utwór czynnego w kilku konwiktach jezuickiej prowincji czeskiej Karla Pelikána (il. 5) ${ }^{54}$, napisany do słów hymnu eucharystycznego św. Tomasza z Akwinu, cenionego również w kręgach jezuickich. Również w roku I68o Panny z wrocławskiego Piasku skopiowały utwór niezidentyfikowanego dotąd czeskiego autora (określanego na karcie tytułowej jako „Krathochwil”); jest to bardzo bogato obsadzone opracowanie dwóch części nieszporów na dzień św. Franciszka Ksawerego (il. 6), notabene nie obchodzonego zbyt uroczyście poza kościołami jezuickimis5.

Z roku I68I pochodzi kopia koncertu O Domine Jesu Karla Raboviusa, jezuity również czynnego głównie w Czechach, a zmarłego w Kłodzku w roku I686 $(\text { il. } 7)^{56}$. Tekst słowny kompozycji sugeruje, że była ona wykonywana przy okazji Nabożeństwa do Pięciu Ran Chrystusa, kultywowanych w jezuickich sodalicjach uczniowskich a popularyzowanych przez misjonarzy z Towarzystwa Jezuickiego ${ }^{57}$. Mistyczną modlitwę o tematyce oblubieńczej zawiera także koncert Ubi eras o bone Jesu (il. 8), przez kopistkę wrocławskich kanoniczek atrybuowany jako utwór jezuity pochodzącego z czeskiej Lanškrouny, Karla Pfeiffera ${ }^{58}$, który w 1. I686-88 był prefektem muzyki jezuickiego konwiktu w śląskiej Opawie. W kompozycji tej Pfeiffer przepisał jednak partie głosów wokalnych i basso continuo z utworu Francesca della Porty o tym samym tytule ${ }^{59}$, dodając do nich partie dwojga

54 PL-Wu RM 6248 (olim: Mq 174; RISM: 3005I0748): AFFECTUS Adorantis | Anime S: Thome De. | Aquino à. 4. | Authore E: | Carolo Pelicano | S: J: | Chori S: Anne | I680, zob.: Václav Kapsa, "Jesuiten komponieren. Bemerkungen zu den erhaltenen Kompositionen der böhmischen Jesuiten”, w: Aurora Musas nutrit - Die Jesuiten und die Kultur Mitteleuropas im I6.-I8. Jahrhundert. Acta conventus, Bratislavae 26.-29. Septembris 2007, red. Ladislav Kačic, Svorad Zavarský, Bratislava 2008, s. 193-208, zob. s. 199-200. PL-Wu RM 47I9 (olim: Mf 642; RISM: 300514478): Dixit Dominus \& Magnificat. | S: Francisci Xauerj̈. $\mid \hat{a}$ Ig. $\mid 2=$ CC. $\mid 2=$ Alt. $\mid 2=$ Tenor. $\mid 2=$ Bafs: $\mid 2=$ Violin. $\mid 3=$ Viole. $\mid 2=$ Clarin. $\mid 4=$ Trombon. $\mid$ Principal. Marte et Tympanis. | Authore. D(omi)no. Krathochwil.

56 PL-Wu RM 6289 (olim: Mq 205'a) RISM: 300510752): O Domine Jefu |a. 3. $\mid$ I-C I I-Vio: | et Viola di $\mid$ Gamba | Chori S. Anna | I68I., zob.: V. Kapsa, op. cit., s. I96-I99. Autor zachowanego nekrologu jezuity (Kraków, Archiwum Prowincji Południowej Towarzystwa Jezusowego, 2549. Defuncti provinciae Bohemiae, s. 64-65) wspomina wprost o talencie kompozytorskim Raboviusa: „Excelluit in componendis Musicæ Modulis; quales complures â fuavitate præfertim, in magna æstimatione habentur. Divino cultui, $\&$ honori, in Seminarijs Artem eandem plurimis annis magnopere promovit”.

57 „O Domine Jesu Christe, Deus cordis mei, vita mea, anima mea, qui natus, passus, mortuus es pro nobis, obsecro te per illa quinque vulnera quae tibi in cruce nostri amor inflixit, obsecro, famulis tuis subveni, quos pretioso sanguine redemisti. Amen”, por.: T. Jeż, op. cit., s. 205.

58 PL-Wu RM 6250 (olim: Mq I76; RISM: 3005I4479): Concertus de S. S. | Nomine JESU | Ubi eras o bone Jefu |Canto et Alto | 2 - Violin | 2 - Viole | et Organo |Authore Carolo Pfeiffer. | Chori S: Anne | I68I, por.: Tomasz Jeż, op. cit., s. 409.

59 RISM A/II: P 5198: MOTETTI | A DVE, TRE, QVATTRO, E CINQVE VOCI | Con vn Magnificat, Litanie della Beata Vergine | à quattro, e cinque, fi placet, | DI FRANCESCO DELLA PORTA | Organifta, \& Maeftro di Capella nella Madonna preffo | S. Celfo in Milano. | LIBRO SECONDO |

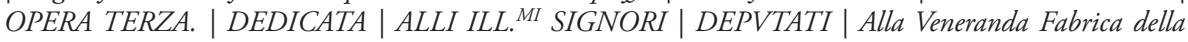

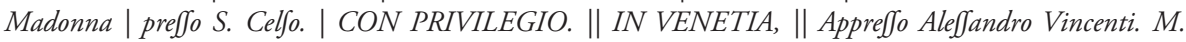
DC. XXXXVIII, nr 4: Vbi eras à 2. Canto, ouer Tenor, è Alto, por.: http://www.printed-sacred-music.org/ manuscripts/oooooooooo2669?peek=I\&wheel=mnskrpt_wf, dostęp I3 VII 2018. 


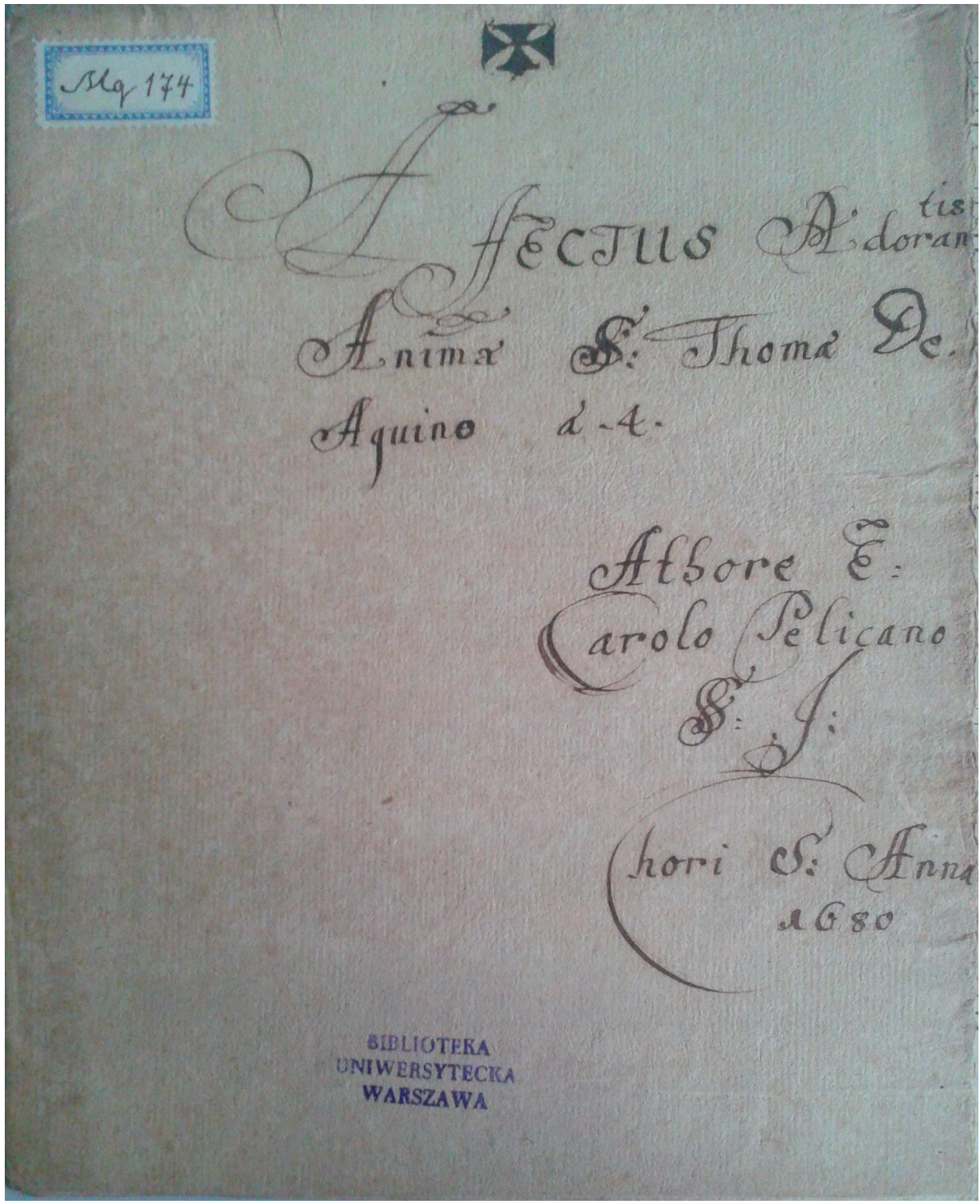

Il. 5. PL-Wu RM 6248, Carolus Pelicanus SJ, AFFECTUS Adorantis Anima [...] ḋ. 4, strona tytułowa. 


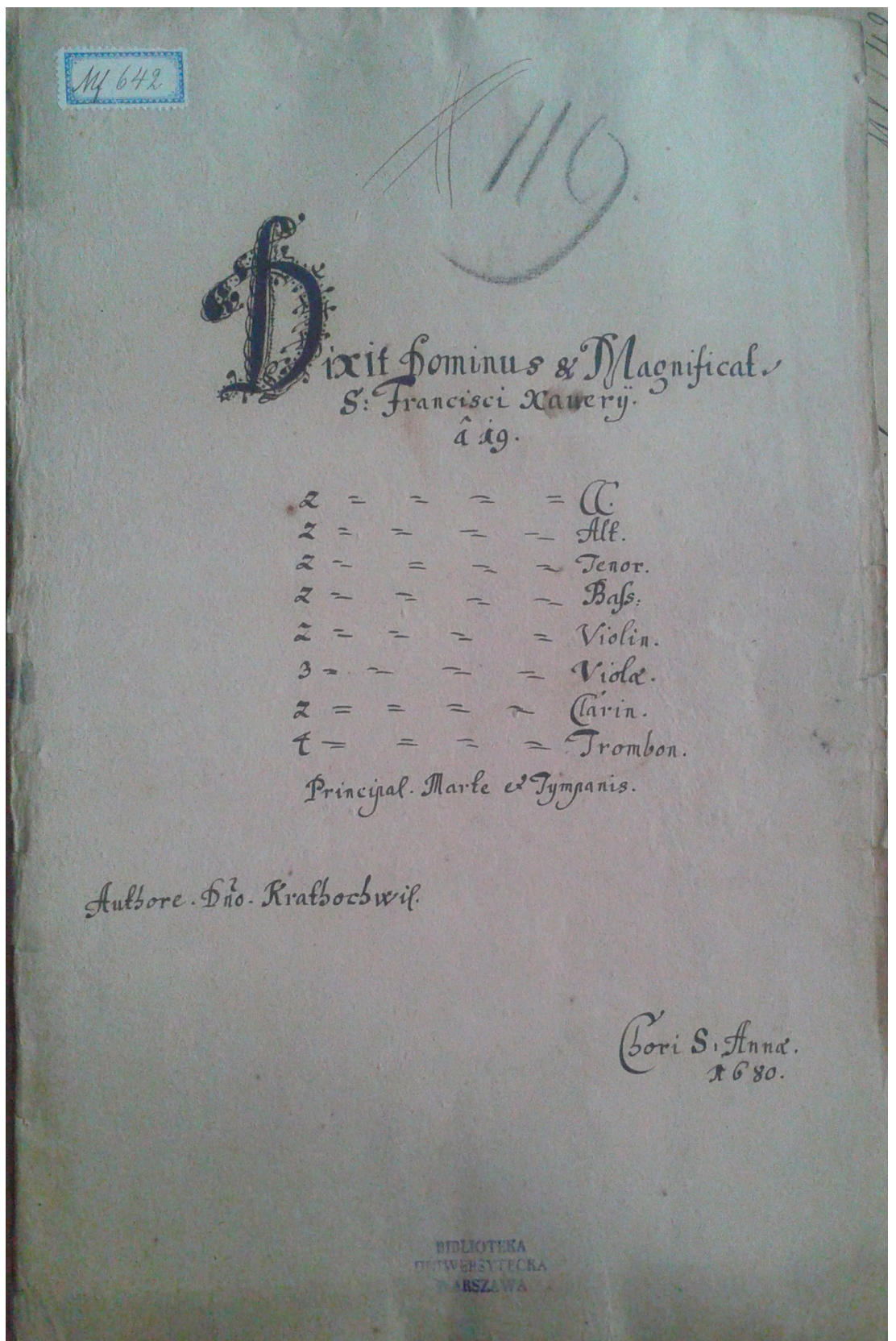

Il. 6. PL-Wu RM 4719, Dixit Dominus \& Magnificat. S Francisci Xauerj. â I9 [...] Authore D(omi)no Krathochwil, strona tytułowa. 


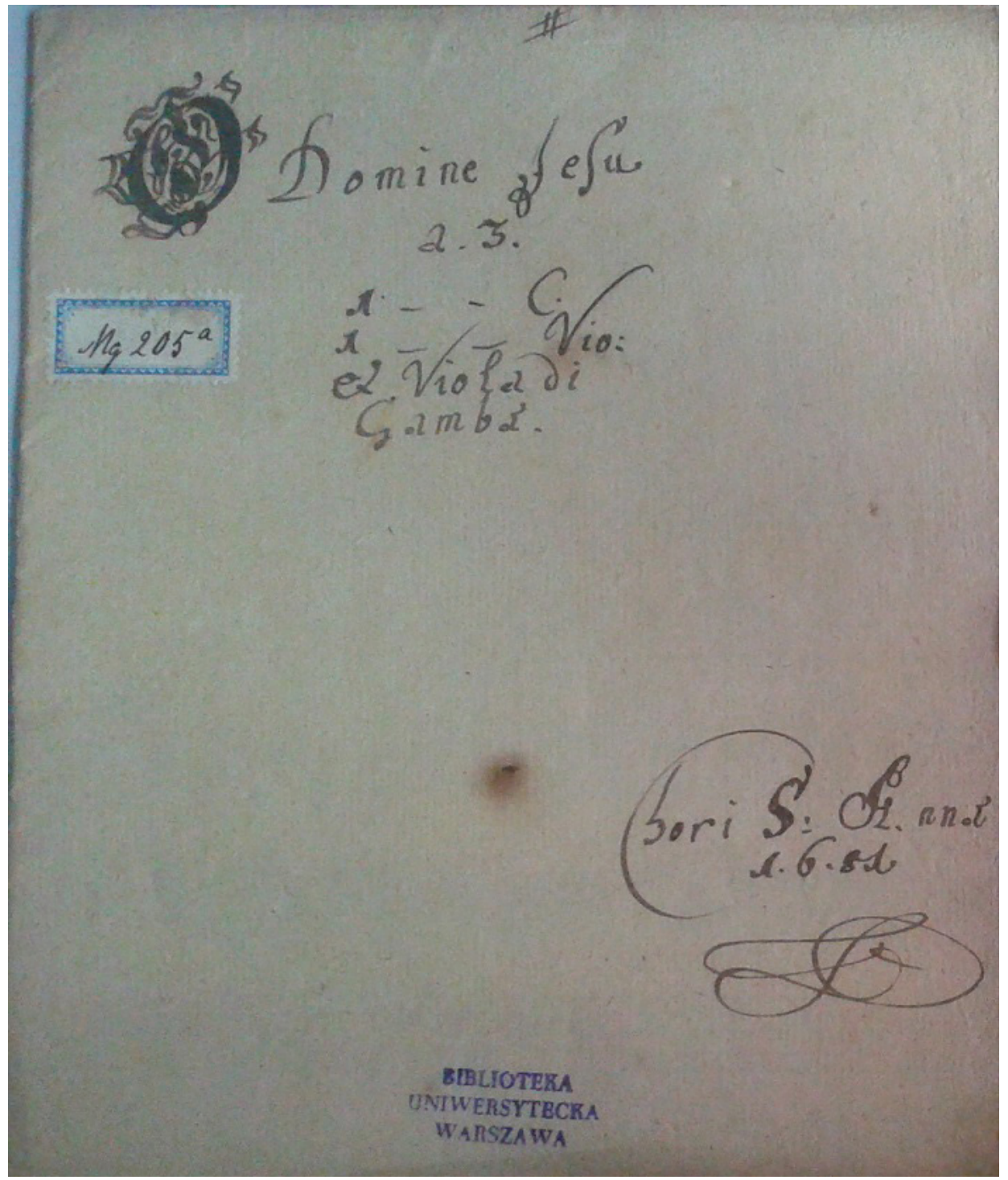

Il. 7. PL-Wu RM 6289, Carolus Rabovius SJ, O Domine Jesu a. 3 [...], strona tytułowa. 


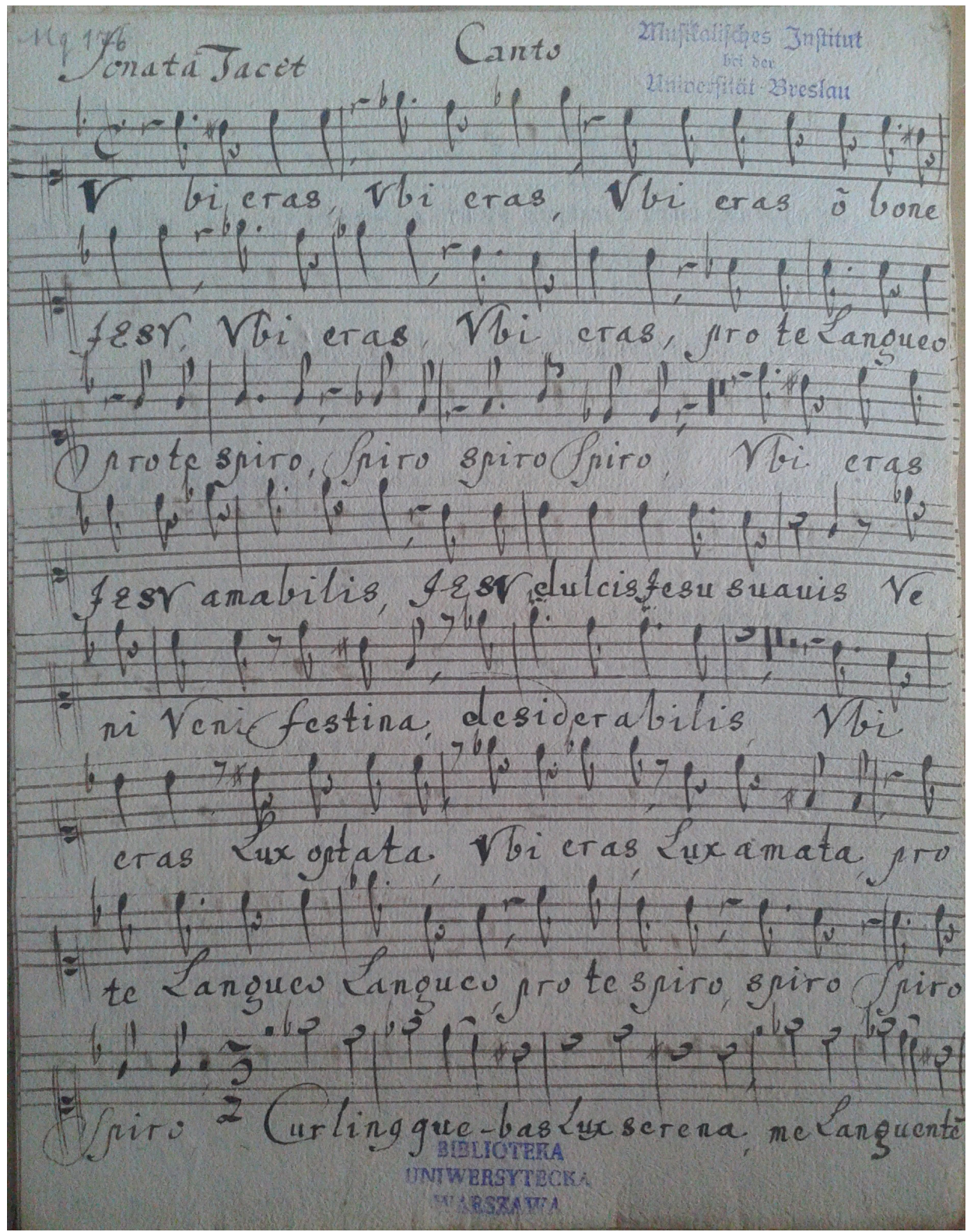

Il. 8. PL-Wu RM 6250, Concertus de S. S. Nomine JESU Ubi eras o bone Jesu [...] Authore Carolo Pfeiffer, głos Canto. 
skrzypiec i dwóch wiol. Być może twórczość włoskiego kompozytora trafiła do Pfeiffera za pośrednictwem sieci kontaktów kulturowych, które wiązały wiele środkowoeuropejskich konwiktów jezuickich z muzycznymi instytucjami tego zakonu w Wiecznym Mieście, m.in. słynnym Collegium Romanum, w którym swego czasu kształcił się Francesco della Porta.

W roku 1682 wrocławskie kanoniczki skopiowały drugi utwór Martina Kretzmera, Aeterne rerum omnium effector Deus ${ }^{60}$, napisany do modlitwy pro conversione infidelium św. Franciszka Ksawerego. Z następnego zaś roku pochodzi przekaz mszy rekwialnej Nicolausa Francisca Frölicha, organisty kościoła parafialnego Wniebowzięcia NMP w Kłodzku, administrowanego w tym czasie przez jezuitów ${ }^{6}$. Kompozytor ten musiał być przez wrocławskie kanoniczki bardzo ceniony, skoro już w roku i683 odpisały one jego offertorium O Maria Virgo pia ${ }^{62}$. W kolejnym roku skopiowały zaś litanię do wszystkich świętych jezuity Joannesa Fabera, w ostatnich latach życia przełożonego sodalicji mieszczańskiej w Nysie ${ }^{63}$. O praktycznym wykorzystaniu tego rękopisu przez wrocławskie kanoniczki świadczy wzmiankowany wyżej dopisek „Verte Maria Teresia”, umieszczony na w partii I skrzypiec ${ }^{64}$; jak również znaleziona wewnątrz tego fascykułu karteczka $\mathrm{z}$ inskrypcją „ut congruentem pluviam fidelibus tuis concedere digneris” (il. 9). Tekst ten to fragment modlitwy towarzyszącej procesji błagalnej o deszcz przewidzianej przez formularz De processione ad petendam pluviam ${ }^{65}$.

Kolejne chronologicznie ślady twórczości jezuickich autorów w muzykaliach klasztoru kanoniczek pochodzą z roku I692: jednym z nich jest odpis koncertu Surgamus, eamus, properemus atrybuowany przez kopistkę jako utwór Karla

60 PL-Wu RM 6226 (olim: Mq I54; RISM: 300510733): Concerto |à 2. C.C. | Aterne rerum omnium effector | DEVS. |Auth(ore) R. P. Martinus Kretzmer S(o)ci(etat) is Jesu | Chori S: Anna. | I682.

6I PL-Wu RM 4368 (olim Mf 304; RISM: 3005I4475): Viaticum Mortuorum. $|\hat{a}|$ I4 Vocibus. | C. A. T. B. 2 C. A. T. B. in Cap: | C. A. T. Viola. A. T. B. Trombon | et Organo. |Authore D: Nicolao Frölich. | Chori S: Anna. | I683, por.: Nicolaus Franciscus Frölich († I708). Viaticum mortuorum, O Maria Virgo pia, Salve Regina, red. Tomasz Jeż, Warszawa 2018 (= Fontes Musicae in Polonia C/IV).

62 PL-Wu RM 6I43 (olim: Mq 79; RISM: 3005IO725): Offertorium | O MARIA Virgo pia in te ó Cali D(omi)na. |ä 17. Vocibus. | C C. A. A. T. T. B. B. V. V. A. T. Viola | Cla: Cla: A. T. B. Trombe. | et Organo. |Authore D(omi)no Nicolao. | Frölich. | Chori S: Anne. | I684.

63 PL-Wu RM 6I40 (olim: Mq 76a; RISM: 300510724: J. M. J. | Lÿtanie de omnibus Sanctis pro | diebus Rogationum. |â ro. Vocibus. | CC. A. T. B. V. V. A. T. B. Viola et in Capella. |Authore R(everen)do P(at) re Joanne Fabro | Soc: Jesu Sacerdote. | Chori S: Anne | I684, por.: Joannes Faber (I600-I667). Litaniae de omnibus Sanctis pro diebus Rogationum a Io, red. Tomasz Jeż, Warszawa 2018 (= Fontes Musicae in Polonia C/VII).

64 Por. przyp. I5. Być może jest to osoba tożsama ze wspomnianą wyżej Marią Theresą Banner(in) Freiin von Siegeskron (I664-1736), od I682 r. zakonnicą wrocławskiego klasztoru kanoniczek regularnych, a w l. 1720-36 przeoryszą tego konwentu i fundatorką ołtarza św. Augustyna w kościele św. Anny, pod którym też została pochowana po swojej śmierci, zob.: H. Hoffmann, Sandstift und Pfarrkirche, op. cit., s. 63 .

65 Liber Usualis with introduction and rubrics in English, Tournai-New York 196I, s. I838. 


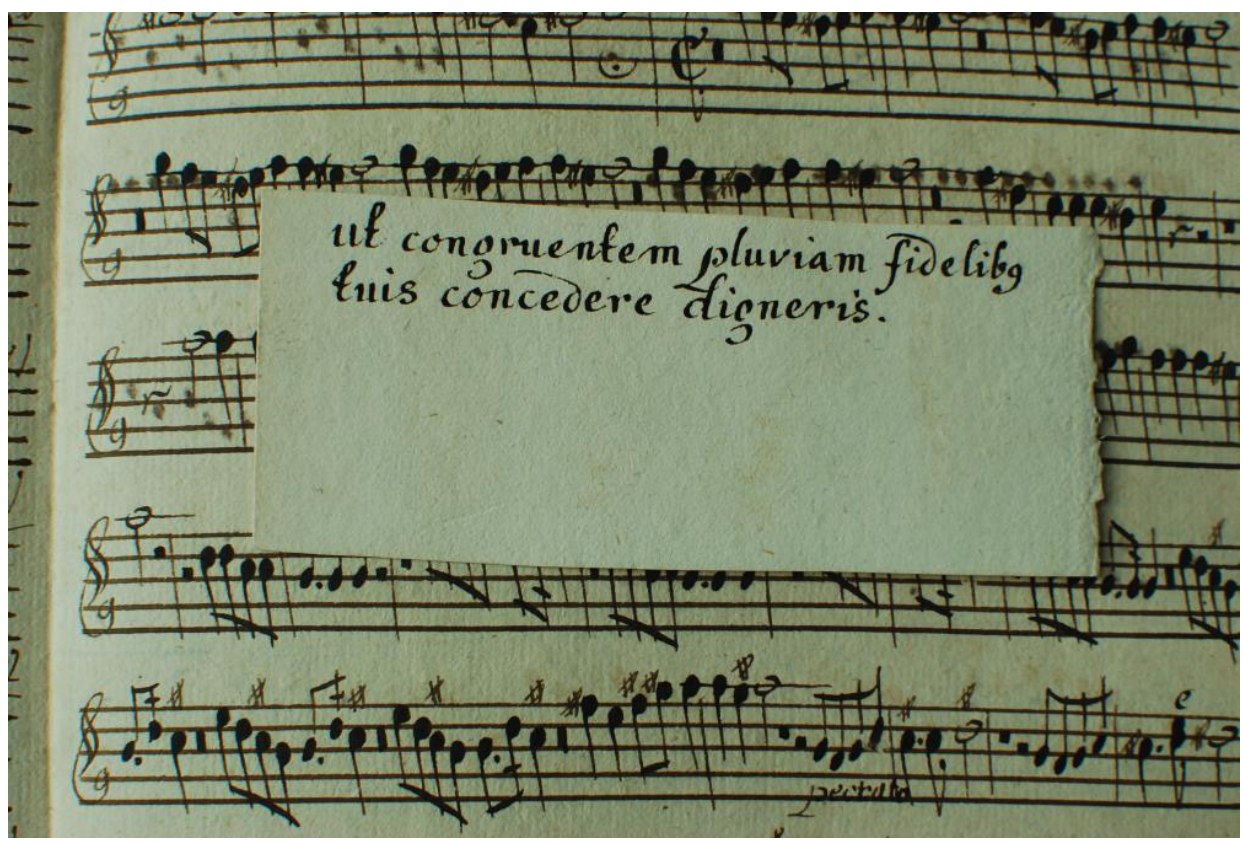

Il. 9. PL-Wu RM 6I40, Joannes Faber SJ, Lÿtania de omnibus Sanctis pro diebus Rogationum. â Io. [...], karteczka z głosu Violino I.

Raboviusa ${ }^{66}$. Podobnie jak poprzednio omawiany utwór Porty/Pfeiffera, także i ten jest aranżacją kompozycji włoskiego autora - Giacoma Carissimiego ${ }^{67}$. Opracowanie Raboviusa opiera się na tym samym wyborze cytatów z biblijnej Pieśni nad pieśniami, cechuje je nadto podobna koncepcja formy i analogiczny sposób kształtowania motywów melodycznych; utwór czeskiego jezuity jest jednak znacznie bogaciej obsadzony niż kompozycja kapelmistrza rzymskiego Collegium Germanicum. W tym samym roku 1692 wrocławskie kanoniczki odpisały koncert In nomine Jesu Georga Brauna, jezuity czynnego w Legnicy i w Nysie, który zgodnie z charyzmatem swojego zakonu zadedykował swój utwór czci Najświętszego Imienia Jezus ${ }^{68}$. Niedatowany

66 PL-Wu RM 6269 (olim: Mq I88; RISM: 300511766): Motteta duo, de B ${ }^{\text {ma }}$ | Virgine Maria. | I $I^{m u(m)}$ Surgamus Eamus. $\mid 2^{\text {du(m) }}$ Salutemus Matrem. $\mid$ A. I7. Vocibus. $\mid 2=$ Cant. $\mid 2=$ Alt. $\mid 2=$ Tenor. $\mid 2=$ Bafs. $\mid 2$ =Violin. $\mid 2$ = Violis. $\mid 2=$ Clarin. $\mid 3$ = Trombon. $\mid$ Con organo. $\mid$ Authore R: P: Carolo $\mid$ Rabovio. S: J: | Chori S: Jacobi $\mid$ I692.

67 R. |FLORIDVS | CANONICVS DE SYLVESTRIS | A Barbarano, | CANTIONES ALIAS SACRAS | ab Excellentifimis Auctoribus concinnatas | fuauifimis modulis | BINIS, TERNIS, QVATERNISQ; VOCIBVS | In lucem edendas curauit. || ROMAE, Ex Typographia Ludouici Grignani I649. || SVPERIORVM PERMISSV, nr I2: Surgamus, eamus, Alto, Ten. e Bafo.

68 PL-Wu RM 6084 (olim: Mq 24; RISM 3005II882): In nomine Jesu. $\mid \hat{a}$ I2. $\mid I=$ Cant. $\mid I=$ Alt. $\mid I=$ Tenor. $\mid I=$ Bafs. $\mid 2$ = Violin. $\mid 3=$ Viole. $\mid 3=$ Trombon. $\mid$ Cum organo. $\mid$ Authore R: P: Georgio. $\mid$ Braun. S: Jesu. $\mid$ Chori S: Jacobi | I692, por.: Georgius Braun (I658-I709). In nomine Jesu, O caelitum Dux, red. Tomasz Jeż, Warszawa 2017 (= Fontes Musicae in Polonia C/II). 
odpis jeszcze jednej jego kompozycji, pastorelli $O$ coelitum Dux, świadczy o zainteresowaniu kanoniczek typowo jezuickim repertuarem bożonarodzeniowych praesepiów $^{69}$. Z następnych już lat pochodzą kopie kolejnych, innych utworów badanej tu proweniencji: Salve Regina Nicolausa Frölicha ${ }^{70}$ i koncert Laudem te Dominum Martina Kretzmera ${ }^{71}$, napisany do tekstu skompilowanego z fragmentów psalmodii oraz pism św. Tomasza z Akwinu i św. Bonawentury.

Prawdopodobnie ostatnim chronologiczne śladem jezuitów w repertuarze wrocławskich kanoniczek jest małogłosowa pastorella bożonarodzeniowa Huc advolate corda clientum (il. Io). Na karcie tytułowej jej odpisu ${ }^{72}$ widnieje następująca atrybucja autorska: „Authore R: P: Liebstein”; najprawdopodobniej chodzi tu o Leopolda Liebsteina, urodzonego 22 II I667 r. w Nysie, który do jezuickiego nowicjatu wstąpił I4 X 1685 r., działał w kilku kolegiach prowincji - m.in. jako prefekt muzyki w Znojmie (I69I/92) i Brnie (I695/96) - a w 1. I703-05 pracował jako profesor filozofii we Wrocławiu. Tam też 2 II I703 r. złożył swoje professio quatuor votorum, a 26 I I705 r. napisał do generała zakonu podanie o misje zamorskie, argumentując je następującymi słowami: „jeśli Bóg życzy sobie, aby filozof zmienił się w muzyka, to on chętnie zaśpiewa"73. Jezuita ten miał zresztą do takiej przemiany stosowne kwalifikacje muzyczne i być może to właśnie dzięki nim otrzymał upragnione pozwolenie na wypłynięcie do Pekinu, gdzie dotarł w roku I707 i działał aż do swojej śmierci 26 IV I7II r. ${ }^{74}$.

69 PL-Wu RM 6085 (olim: Mq 25; RISM: 300514II7): Pastorella Natalitia | O! Calitum Dux | Alto Solo | Violino $-I \mid$ Violetta $-I \mid$ con $\mid$ Organo $\mid$ Auth: R. P. S. J. | Braun S. J. P.

70 PL-Wu RM 6I44 (olim: Mq 80; RISM: 300514476): Salue Regina |â 9. Voc. |I. Cant: ::2 Violin| 3 Tromb. 2 Viola | et Canto Ripien | Cum Bafso pro Organo |Authore | Nicolao Frölich | Organista Glaceno.

7I PL-Wu RM 6227 (olim: Mq I55; RISM: 3005II832): Motettum de Tempore. $\mid$ à II. $\mid 2=$ Cant. $\mid I=$ Alt. $\mid 2=$ Tenor. $\mid I=$ Bafs. $\mid 2=$ Violin. $\mid 3=$ Trombon. $\mid$ \& Organo. $\mid$ Authore R: P: Kretzmer. $\mid$ Chori S: Jacobi. $\mid$ I6g8.

72 PL-Wu RM 6234 (olim: Mq I62; RISM: 300511835): Aria Natalitia. | a.. 4. | Canto Solo. Violin. 2. | Con Basso. | Authore R: P: Liebstein. | Chori S: Jacobi. | I708.

73 Carlos Sommervogel SJ, Bibliothèque de la Compagnie de Jésus. Première partie: Bibliographie par les Pères Augustin et Aloys de Backer SJ. Seconde partie: Histoire par le Père Auguste Carayon SJ. Nouvelle édition par Carlos Sommervogel SJ, t. I-II, Bruxelles-Paris I890-1930, t. 4, I893, s. I8IO; Anton Huonder, Deutsche Jesuitenmissionare des 17. und I8. Jahrhunderts Ein Beitrag zur Missionsgeschichte und zur deutschen Biographie, Freiburg im Breisgau I899, s. 191; Hermann Hoffmann, Schlesische, mährische und böhmische Jesuiten in der Heidenmission, Breslau 1939 (= Zur schlesischen Kirchengeschichte 36), s. II, 4I; Ludger Müller, „Lebensbilder schlesischer Jesuitenmissionare im 17. und I8. Jahrhundert”, Archiv für Schlesische Kirchengeschichte 43 (1985), s. 165-220, s. 169, 216; Markéta Holubová, Biografický slovnik hudebnich prefektů jezuitského rádu piosobicich v Čechách, na Moravĕ a ve Slezsku v letech I556-I773, Praha 2009, s. 87.

74 W katalogu nowicjuszy z Brna z roku I686/87 napisano przy jego nazwisku „callet musicam”, zob.: Félix Zabala Lana SJ, Músicos jesuitas a lo largo de la historia, Bilbao 2008, s. 136. 


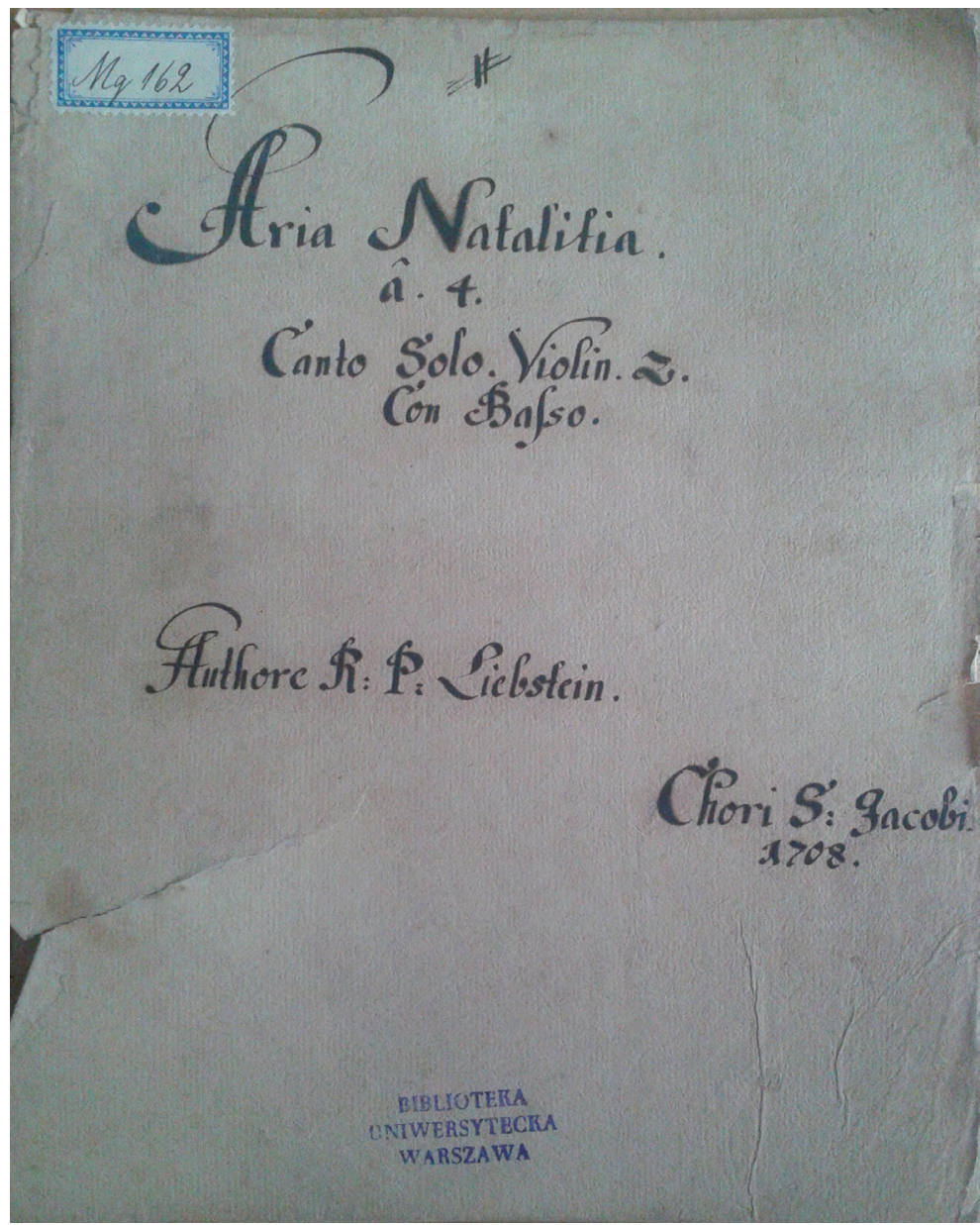

Il. Io. PL-Wu RM 6234, Aria Natalitia. â. 4. [...] Authore R P Liebstein, strona tytułowa

Dowodem talentu muzycznego nyskiego jezuity jest nieznana dotąd jego kompozycja, której transkrypcję umieszczamy na końcu niniejszego artykułu. To kolejny utwór napisany przez śląskiego jezuitę, który dzięki kopistkom z wrocławskiego konwentu kanoniczek zachował się do naszych czasów i wymownie świadczy o tradycjach muzycznych obydwu tych zgromadzeń zakonnych, jak również o wiążących je relacjach kulturowych. Podobnie jak wspomniana wyżej pastorella Brauna, utwór Liebsteina to prosta stroficzna ,aria”, przeznaczona do wykonania przy okazji bożonarodzeniowego praesepium, urządzanego często nie tylko przez jezuitów w Nysie, ale także kanoniczki we Wrocławiu. Tekst słowny kompozycji odwołuje się do różnych nurtów barokowej duchowości, które można powiązać z wymienionymi wyżej inspiracjami teologicznymi. Opracowanie muzyczne utworu Liebsteina doskonale się mieści w konwencji barokowej pastorelli, stylizowanej za pomocą charakterystycznego dla włoskiej 
siciliany metrum 6/8 i quasi-pieśniowego konturu melodyki ${ }^{75}$. Na uwagę zasługują dość samodzielnie traktowane partie obojga skrzypiec w dwudziestoczterotaktowym interludium oddzielającym od siebie kolejne strofy tekstu.

Utwory dziewięciu kompozytorów jezuickich, które trafiły do zbiorów konwentu św. Anny na Piasku, potwierdzają żywe zainteresowanie wrocławskich kanoniczek twórczością muzyczną kompozytorów działających w środowisku Towarzystwa Jezusowego. Teksty słowne tych kompozycji odnoszą się do różnych aspektów ignacjańskiej duchowości i jezuickiej praktyki duszpasterskiej, co sugeruje bezpośrednie związki wrocławskiego konwentu z tym środowiskiem zakonnym; zarówno w sferze duchowości, jak i form jej pielęgnowania. Poza autorami czynnymi w pobliskich centrach muzycznych tego zakonu - w Nysie, Wrocławiu, Opawie i Legnicy - kanoniczki chętnie kopiowały utwory jezuickich kompozytorów aktywnych w miastach Korony Czeskiej, m.in. w Kłodzku, Ołomuńcu i Pradze. Niektórzy z tych autorów sami zresztą dokonywali aranżacji dzieł włoskich twórców (zgodnie z ówczesną praktyką kompozytorską niekoniecznie się do tego przyznając). Do spuścizny muzycznej europejskich autorów wrocławskie kanoniczki docierały również za pośrednictwem innych zakonów, w szczególności franciszkanów i cystersów, którzy razem z jezuitami kształtowali potrydenckie nurty duchowości, nie tylko na terenie Śląska.

Ślady wspólnego oddziaływania tych zakonów widoczne są także w samym repertuarze muzycznym Panien z Piasku: są to m.in. kompozycje oparte na tekstach mistycznych o tematyce oblubieńczej: od Augustyna po Franciszka Ksawerego. Muzyczne ich opracowania stanowią w większości krótkie małogłosowe koncerty kościelne, przeznaczone na I-2 wysokie głosy wokalne i niewielki skład instrumentalny, skupiony wokół sekcji basso continuo. W kopiowanym przez kanoniczki repertuarze uwage zwracają jednak kompozycje przeznaczone na znacznie większą obsadę, wymagające często nawet kilkunastoosobowego zespołu. Jeśli utwory te faktycznie służyły chórowi kościoła św. Jakuba, musiały być wykonywane przez niemal wszystkie zakonnice konwentu (!), co teoretycznie było możliwe, skoro działały w nim aż dwie kantorki i dwie zakrystianki. Być może jednak w wykonaniach muzycznych odbywających się w kościele wrocławskich kanoniczek uczestniczyli także muzycy wypożyczani z innych ośrodków miasta: działającej przy ich klasztorze szkoły, kapeli sąsiadującego konwentu kanoników NMP, bądź nieodległego jezuickiego konwiktu św. Józefa, za pośrednictwem którego jezuicki repertuar muzyczny trafiał ad usum „chori S. Annae” a później „chori S. Jacobi”. Odpowiedź na to pytanie niewątpliwie przybliżą dalsze badania nad historią i repertuarem kanoniczek z wrocławskiego Piasku.

75 Por.: Hyacinthus Szczurowski (I7I6? - po I774). Missa Emmanuelis, red. Maciej Jochymczyk, Warszawa 2018 (= Fontes Musicae in Polonia C/VIII), s. I4. 


\section{ANEKS}

[LEOPOLD?] LIEBSTEIN, ARIA NATALITIA A 4: HUC, HUC ADVOLATE.

W prezentowanej poniżej edycji brakujące $\mathrm{w}$ źródle akcydencje, nuty, pauzy i fragmenty tekstu uzupełnione zostały w nawiasach kwadratowych. Ujednolicono stosowanie wielkich liter i znaków interpunkcyjnych. Usunięto niesystematycznie umieszczane przez kopistkę łuki służące oznaczeniu melizmatów, jak również tautologiczne znaki chromatyczne. Akcydencje umieszczane nad nutami, a odnoszące się do wysokości dźwięku, przeniesiono przed odpowiadające im nuty. Bemole używane w źródłach w funkcji kasowników zastąpiono kasownikami. Cyfrowania niekompletnego nie uzupełniano; zachowano oryginalną jego postać, m.in. posługiwanie się znakiem bemola w funkcji kasownika i niekonsekwentne stosowanie krzyżyków dla oznaczenia trybu durowego. W poniższych uwagach szczegółowych pierwsza liczba oznacza numer taktu, po kropce następuje nazwa głosu, cyfra po średniku oznacza kolejną nutę w takcie, po dwukropku podana jest sytuacja w źródle. Na przykład: 3. C; 4: $a^{1}$, oznacza, że w takcie $3 \mathrm{w}$ sopranie czwartą nutą jest $a^{1}$ :

Zastosowane skróty: C - canto, I - primo, II - secondo, Org - organo,

$\mathrm{Vlc}$ - violoncello, $\mathrm{Vl}$ - violino

23. Vlc, Org; przed I: \#w funkcji h

23. C. przed 5: \#w funkcji

26. Org; nad 2: ${ }^{6}$ (przeniesiono nad I)

27. Org; nad 2: ${ }^{6}$ (przeniesiono nad I)

35. Vlc, Org; nad I-3: „fides”

4O. Vl II; I: $f^{2}$

4I. Vl II; I: $c^{2}$

47. Vl I; I: $d^{2}$

47. Vl II; $4: d^{2}$

5I. Vl II; przed I: \#w funkcji

5I. Vlc, Org; przed 3: \#w funkcji

58. Vl I; $2-3$ i $5-6: a^{2} f^{2}$ 


\section{Aria Natalitia}

Huc, huc advolate

R: P: Liebstein
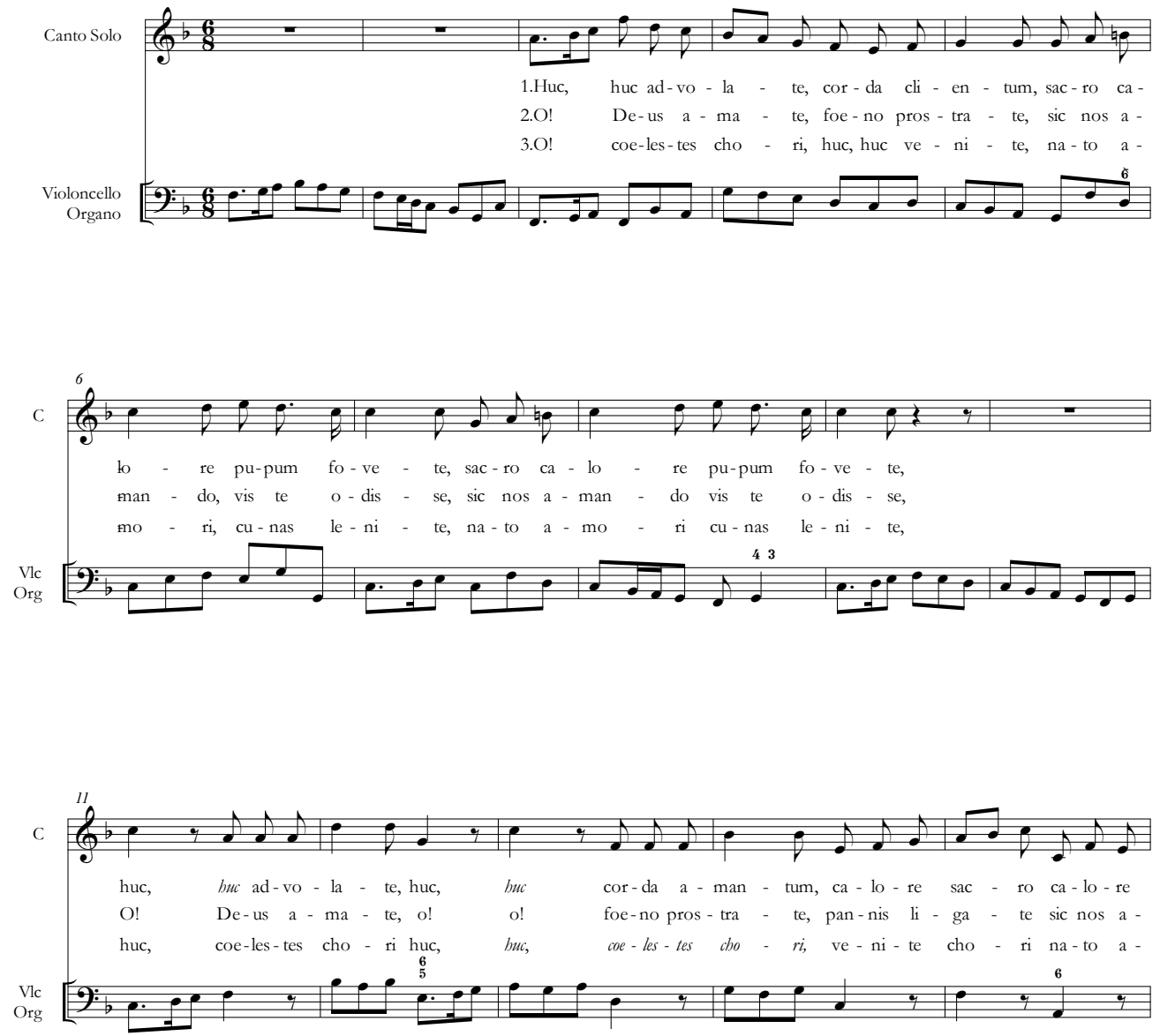

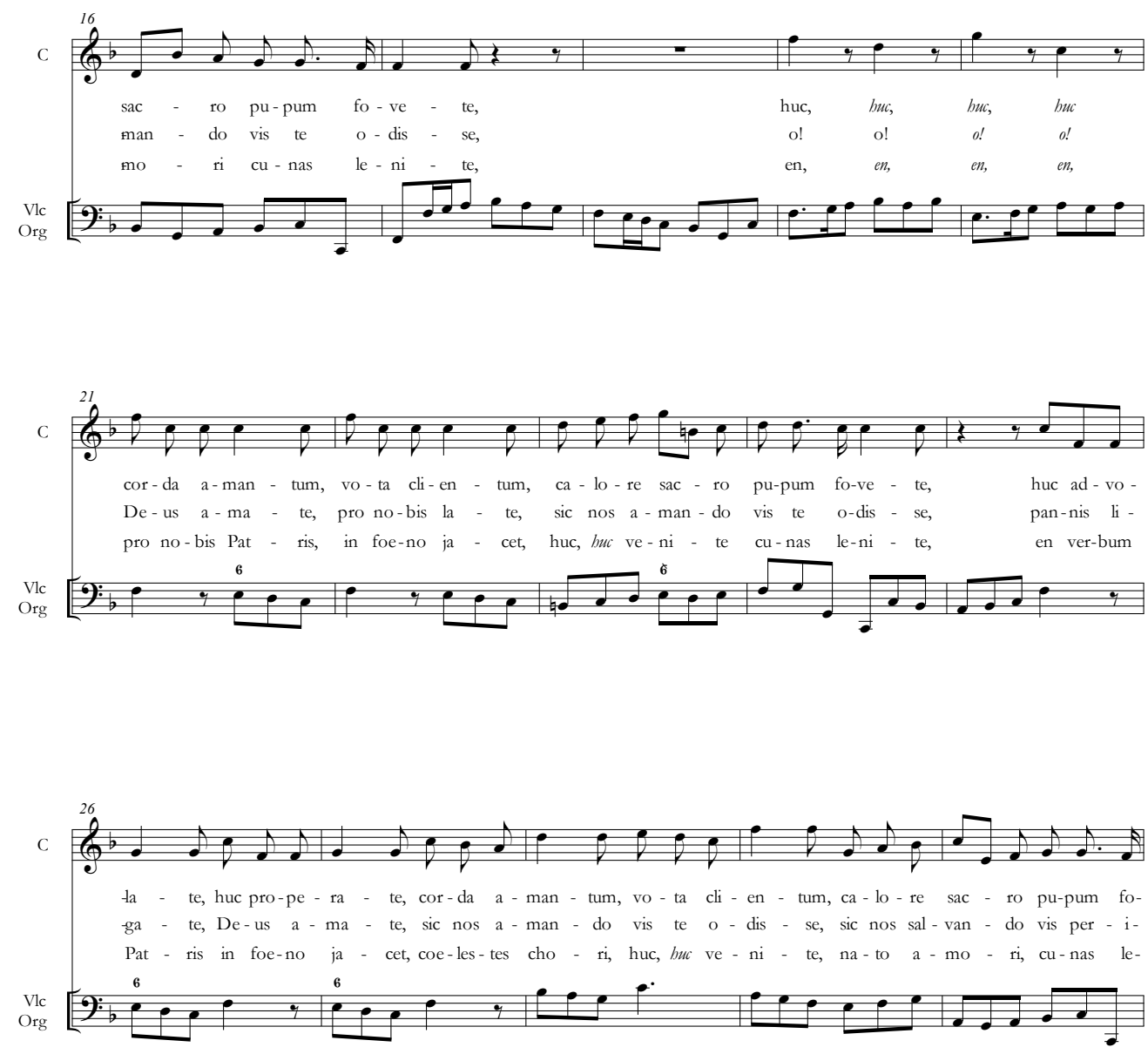

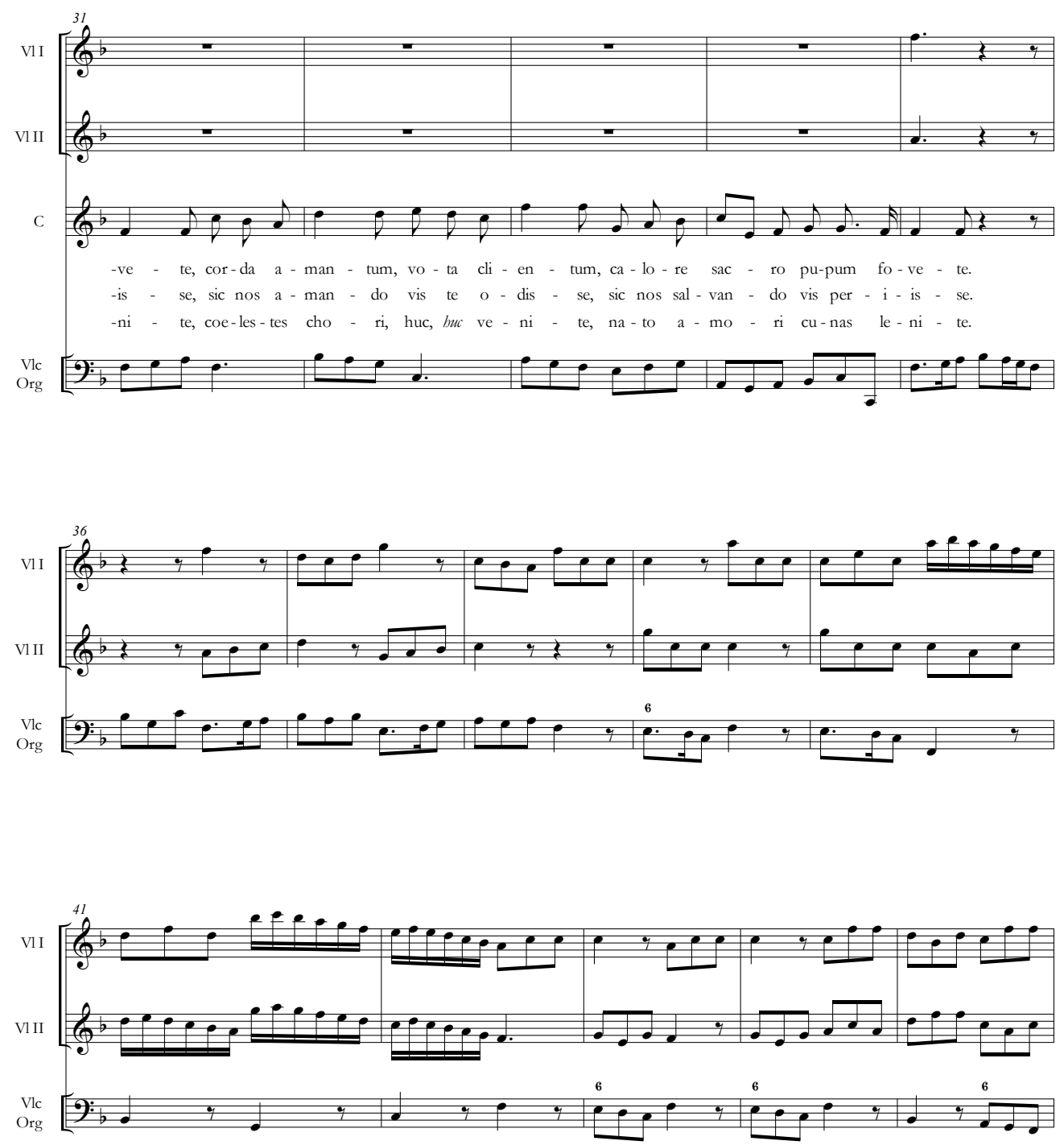

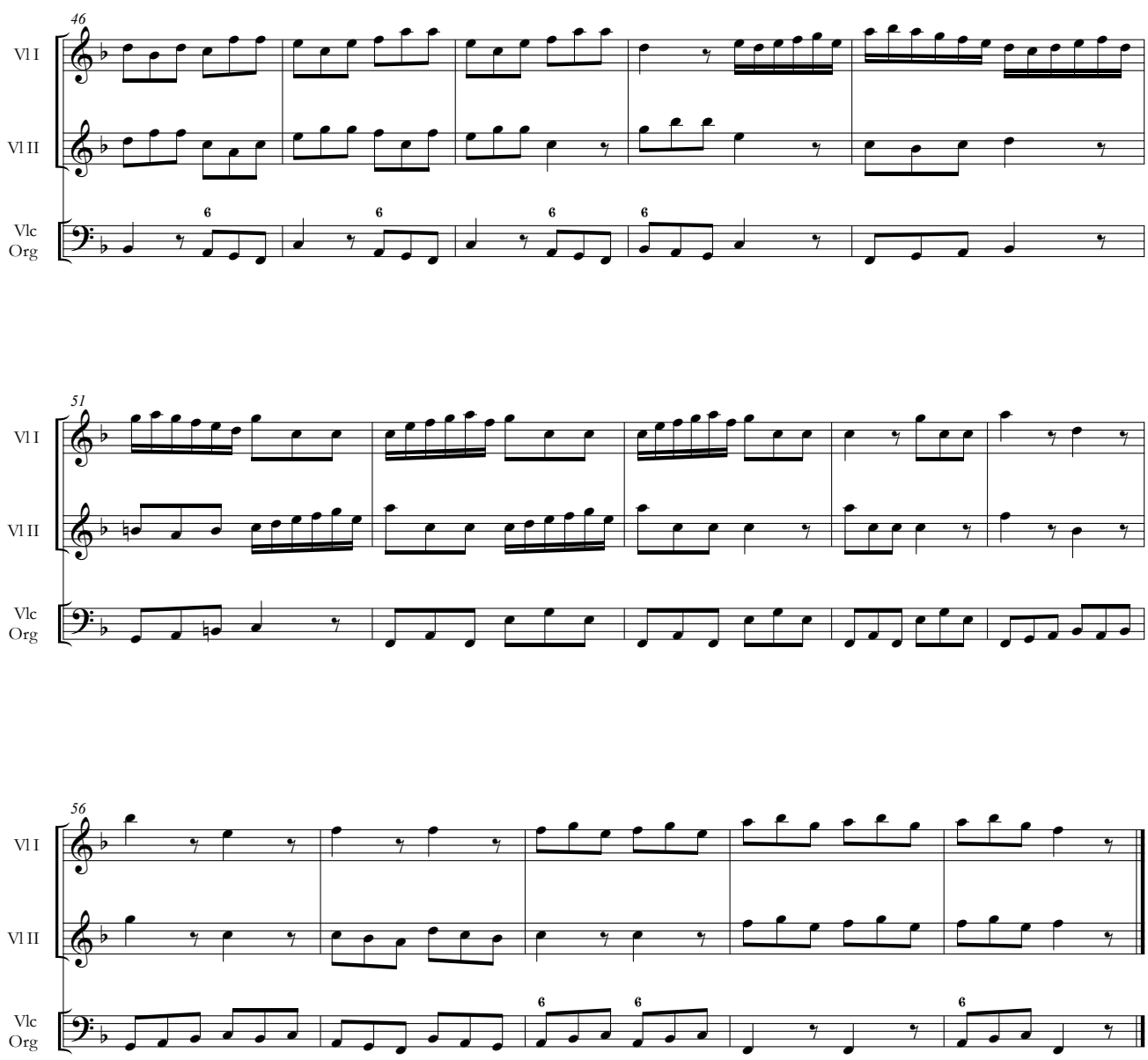


\section{THE JESUIT MUSIC REPERTOIRE AT THE CONVENT OF CANONESSES REGULAR IN WROCŁAW}

The collection of music manuscripts that once belonged to the Canonesses Regular of Wrocław (now part of the Music Collection of the University of Warsaw Library) is a set of more than 450 music sources, unique in Poland, coming from the late 17 th and early I8th centuries. The sources bear the provenance marks of Chori S. Annae and Chori S. Jacobi. The repertoire contained in those sources testifies to the originality and very high standards of music traditions cultivated by the canonesses, but also to their convent's wide contacts with numerous institutions of music culture in both Silesia and the neighbouring countries. Some of the music manuscripts confirm the Wrockaw convent's links to those monastic communities elsewhere in Europe which at that time were the main promoters of new trends and stylistic tendencies in music. Of special interest in this group are compositions derived from the Jesuit circles, which once formed the most dynamically expanding network for the transmission of music culture. They are works by such Jesuits as Georg Braun, Joannes Faber, Martin Kretzmer, Leopold Liebstein, and Carolus Pfeiffer (though the piece attributed to that last composer may in fact have been written by Francesco della Porta). The collection also includes unique copies of liturgical works by Nicolaus Frölich, who for more than 40 years served as organist of the Jesuit Church of the Assumption of the Virgin Mary in Kłodzko. The canonesses of Wrocław also collected anonymously transmitted works which demonstrate evident characteristics of music then popular in the Jesuit circles.

Translated by Tomasz Zymer

Słowa kluczowe / keywords: Wrocław, muzykalia / music-related sources, kanoniczki / canonesses, jezuici / Jesuits, repertuar muzyczny / music repertoire

Dr hab. Tomasz Jeż studiował muzykologię w Warszawie, Getyndze i Berlinie. Po promocji doktorskiej został zatrudniony na Uniwersytecie Warszawskim. W ramach programu „Kolumb” Fundacji na rzecz Nauki Polskiej odbył w roku 2007/o8 staż naukowy w Archivum Romanum Societatis Iesu. Jest autorem czterech książek i ponad sześćdziesięciu artykułów, poświęconych zagadnieniom źródłoznawczym i ideowym aspektom kultury muzycznej. Jego głównym polem badań jest kultura muzyczna Śląska oraz Polski w XVI, XVII i XVIII wieku. Jest kierownikiem projektu badawczego pt. Repertuar muzyczny Towarzystwa Jezusowego w Rzeczpospolitej Obojga Narodów (I565-I773), finansowanego przez Ministra Nauki i Szkolnictwa Wyższego w ramach programu „Narodowy Program Rozwoju Humanistyki”. Wyniki badań uczestników tego projektu publikowane są w serii Fontes Musicae in Polonia, obejmującej katalogi muzykaliów, edycje faksymilowe źródeł, monografie tematyczne oraz edycje krytyczne repertuaru muzycznego. Ukazują się one równolegle w wersji drukowanej oraz w plikach pdf, dostępnych na stronie www.fontesmusicae.pl tomasz.jez@uw.edu.pl 